Portland State University

PDXScholar

1972

\title{
Children Without Futures: a Feasibility Study Comparing Characteristics of Families Who Have Children Placed in Long and Short-term Foster Care
}

\author{
Kaye Hutchins \\ Portland State University \\ Rose Mary McCarthy \\ Portland State University \\ Jim C. O'Neal \\ Portland State University \\ David Radke \\ Portland State University \\ Richard Rankin \\ Portland State University \\ Follow this and additional works at: https://pdxscholar.library.pdx.edu/open_access_etds \\ Part of the Social Work Commons \\ Let us know how access to this document benefits you.
}

\section{Recommended Citation}

Hutchins, Kaye; McCarthy, Rose Mary; O'Neal, Jim C.; Radke, David; and Rankin, Richard, "Children Without Futures: a Feasibility Study Comparing Characteristics of Families Who Have Children Placed in Long and Short-term Foster Care" (1972). Dissertations and Theses. Paper 1692.

https://doi.org/10.15760/etd.1691

This Thesis is brought to you for free and open access. It has been accepted for inclusion in Dissertations and Theses by an authorized administrator of PDXScholar. Please contact us if we can make this document more accessible: pdxscholar@pdx.edu. 
CHILDREN WITHOUT FUTURES:

A FEASIBIIITY STUDY COMPARING CHARACTERISTICS OF FAMILIES WHO HAVE CHILDREN PLACED IN LONG AND SHORT-TERM FOSTER CARE

by

KAYE HUTCHINS

JIM C . O'NEAL

ROSE MARY MCCARTHY

DAVID RADKE

RICHARD FANKIN

A report submitted in partial fulfillment of the requirements for the degree of

MASTER OF SOCIAI WORK

Approved:

Crack C. Finley, Chairmar

Charles Camplan

Portland State University

1972 


\section{ACKNOWLEDGMENTS}

We wish to express appreciation to many people for their aid in the preparation of this study. We are grateful to Mr. Clarence Miller, Administrator of Vancouver office, Division of Public Assistance, for his cooperation in providing us with the case material used for our study and staff members who gave us their time so wlilingly: Mrs. Olive Vining and Mr. Edward Cotter.

We appreciate the guidance and constructive criticism offered by Arthur C. Emlen, Associate Professor of Social Work.

Above all, we thank our patient and tolerant advisors, Jack Finley and Charles Camplan. Their unequalled encouragement and guidance helped us more than we can ever fully acknowledge. 
TABLE OF CONTENTS

PAGE

ACKNOWLEDGMENTS . . . . . . . . . . . . . . . . 11

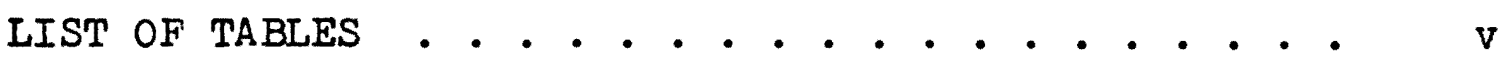

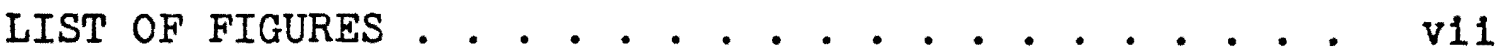

INTRODUCTION . . . . . . . . . . . . . . . . . 1

CHAPTER

I. DESCRIPTION OF THE PROBLEM . . . . . . . . . 3

II. METHODOLOGY . . . . . . . . . . . . . . 15

INTRODUCTION . . . . . . . . . . . . . 15

DESCRIPTION OF THE AGENCY AND COMMUNITY • . 16

IIMITATIONS OF USING CASERECORDS . • . • . . 19

SELECTION PROCESS AND BRIEF DESCRIPTION

OF CASES . . . . . . . . . . . . . 21

PROCESS OF DATA COLLECTION AND ANALYSIS • • 25

III. RESULTS • . . . . . . . . . . . . . 30

INTRODUCTION • • • . . . . . • . • . 30

PARENTAL CHARACTERISTICS . . . . . . . . 36

FAMILY CHARACTERISTICS . . . . . . . . 63

IV. IMPLICATIONS . . . . . . . . . . . . . 101

LIMITATIONS . . . . . . . . . . . . 101

AGENCY NETWORK AS A VARIABLE . . . . . . 104

INIERENCES AND IMPIICATIONS FOR FURTHER

RESEARCH . . . . . . . . . . . 107 
FACTORS NOT EXAMINED . . . . . . . . . . 119

CONCLUSION . . . . . . . . . . . . . 120

IIST OF FOOTNOTES - . . . . . . . . . . . . . 122

BIBLIOGRAPHY . . . . . . . . . . . . . . . 126 


\section{LIST OF TABLES}

TABLE

PAGE

I. Blrthplace of Parents . . . . . . . . . 37

II. Age of Parents at Placement . . . . . 38

III. Age of Parents at Marriage . . . . . . . 40

IV. Number of Marrlages . . . . . . . . 42

V. Number or Separat1ons . . . . . . . . 44

VI. Marltal Status at Placement . . . . . . . 45

VII. Education of Parents .......... 46

VIII. Employment . . . . . . . . . . . . 48

IX. Physical Health of Parents . . . . . . . 50

X. Mental Health of Parents . . . . . . 53

XI. Caseworker's Perception: Positive Versus

Negative Statements . . . . . . 55

XII. Developmental History (Parent's Evaluation) . . 56

XIII. Developmental History - By Factors . . . . 57

XIV. Alcohol/Drug Use . . . . . . . . . 59

XV. Arrests/Confinements ......... 50

XVI. Mothers Pregnant at the Time of Current

Marriage ............. 61

XVII. Mothers Pregnant at the Time of First

Marriage .............. 61

XVIII. Military Service ............ 62

XIX. Religion .............. 62 
TABLE

PAGE

XX. Families Having Provided Out-of-Home

Care to Chilaren Previous to Placement . . . . . . . . . . . .

XXI. Age of Children (At Placement) . . . . 70

XXII. Parental Att1tudes . . . . . . . 72

XXIII. Parent-Child Relationships ....... 74

XXIV. Children's Functioning (By Family) . . . 76

$\mathrm{XXV}$. Housing . . . . . . . . . 78

XXVI. Housing Condition - Meeting Community

Standards at Placement . . . . . . 80

XXVII. Family Financial Situation - Income:

Source and Use.......... 83

XXVIII. Family Financial Situation - Money

Management .......... 85

XXIX. Extended Family and Friends . . . . . 86

XXX. Length of Prior Contact With Public

Assistance Agency . . . . . . 87

XXXI. Protective Services Unit Involvement . . 88

XXXII. Communtty Agencies Involved (Other Than

Fublic Ass1stance) . . . . . . 90

XXXIII. Voluntary/Involuntary Placement . . . . 92

XXXXY. Complaints of Parental Care....... . 93

XXXV. Reason for Placement ......... 95 


\section{LIST OF FIGURES}

FIGURE

PAGE

I. Age of Mothers at Placement - Murphy's

Pattern............ . . . 39

II. Number of Children in Home (At Time of

Placement) . . . . . . . . . . . 64

III. Total Living Children . . . . . . . . . 64

IV. Number of Children Placed Out of Total in

Home at Time of Placement . . . . . . . 66 


\section{INTRODUCTION}

Many children drift into unplanned long-term foster home care, under conditions unsatisfactory for the child, his own family and the foster parents. Current practice in foster care often contributes to foster children growing up without the necessary love, support and guldance from a family that he can call his own. Recent publications in sociai work journals have suggested that a lack of consistent family relationships may be infurious to the emotional development of children. Social workers have become increasingly dissatisfled with a "helping process" that may, in fact, generate more harm than help. Originating from the soclal worker's dissatisfaction with the foster care system is an awareness that some method for evaluation of parenting potential is a critically important factor if the goal of responsible planning for foster home placement is to be attained. One possible method for evaluating parenting potential is to analyze the parents' history of adaptation through an examination of case record material. The purpose of our study is to determine the feasibility of the case anaiysis method as a tool for the development of predictive criterla designed to evaluate "potential for parenting" and thus, ald in more adequate foster care planning. In order to identify criteria for evaluation, it 
appearea that a comparison of fam111es, who were able to resume their parenting role following a brief placement of their children in foster care, with those families whose children required long-term placement, should provide a base level of differences and similarities with predictive significance. 


\section{CHAPTER I: DESCRIPTION OF THE PROBLEM}

There is a growing body of knowledge in developmental psychology and dynamic psychiatry that emphasizes the signiflcance of the family to the child's physlcal development, formation of the psychic structure and social responsibil1ty. The import of the relationship of a maturing child to his family unit has been incorporated into the philosophy and standards for foster family care. The ultimate alm set forth in the 1959 Child welfare League Standards for Foster Family Care, in cases when the family group is incomplete or when it fails to function because of internal conflicts, is to rehabilitate the home with the objective of returning the child to normal family $11 f e .1$ A number of special services are rapidly being refined and expanded to support and strengthen family functioning, such as the homemaker and day care services. In some cases these special services successfuliy prevent the placement of the child into a foster home. In situations when foster home placement is indicated the helping professions, social work, clinical psychology and psychlatry, are summoned to restore the functioning of the family to its optimum level with the goal of returning the child to his family.

Focused on rehabilitation, the helping professions are committed to the concept that therapeutic measures make behavioral changes possible. The development and applica- 
tion of recent knowledge and skills by the helping disc1plines has demonstrated that many troubled parents can be assisted in improving their functioning within the parenthood role. Published accounts of successful treatment with highly motivated families has contributed to a growth of unrealistic optimism about the degree of sophistication of our treatment skills. The Child Welfare League recognized the relationship of the client's motivation to his chances for successful treatment when they wrote that "the most important criteria for determining whether placement is necessary is the capacity of the parents to cooperate with the agency and use the services offered." 2 There has been a reluctance to consider client's motivation in the appraisal of the profession's level of effectiveness. One resulting dilemma can be understood in terms of the current problems in the foster care system. Presently, the Child Welfare Standards view all foster care placements as "temporary"; whereas in reality, the current statistics point to the fact that nearly one-half of all children placed remain in foster care for over three months, and a substantial number of these remain in care one year, and often unt1l adulthood. 3 Consequentiy it is time for the helping professions to recognize that at the current level of sophistication within the behavioral sciences, there remain some parents for whom the most highly skilled professionals, operating 
within the restraints of present operating budgets, cannot effect change in time for them to meet the social and emotlonal needs of their children. 4 Perhaps our current knowledge is insufficlent, or we are unable to do enough to give the kind of assistance required. Regardless, it is our position that efforts should be directed toward protection of chlldren who are not recelving the care and nurturance essential for them to develop to their fullest potentlal. The implication of our study is not necessarily to advocate involuntary removal of chlldren from their natural parents, but rather, the improvement of foster care planning and therefore, services to those children placed by their parents and the courts. Our impressions for the improvement of foster care services emphasize the need for individual planning at the earliest possible moment in the event of foster home placement. Additionally, the value of offering permanent foster care as an alternative cholce to "temporary foster care" has become apparent to us from our review of the literature and the previously clted statistics for foster care.

The authority for determining and arranging appropriate foster family care sultable for each child now rests with the children's service worker. Caseworkers, for the most part, are clearly aware of the serious impact their 
decisions have on both the child and his family. The dif.ficulty of making decisions in the interest of the child is complicated by the inability of our soclety to clearly and concretely define the nature of children's versus parental rights. A question that is often asked by workers is whether

- . the child has the right to be nurtured by parents who love him, want him and can give him the physical care and guidance that he needs or is he the property of his biological parents, who are free to treat him according to their wishes. 5

Complicated by strong emotions and powerful assumptions, this difficult question remains unanswered. Although society has not formulated its final answer, a discernible trend is apparent.

A brief overview of the history of children's versus parental rights will illustrate this point. In anclent Rome 1t was legal for a father to kill his children. In the old Roman family 1t was taken for granted that the "pater fam1Ilas" had the power of life and death over his children. 6 This attitude prevalied for centuries. The English Common Law marked the beginning of change in parental rights when It recorded that the "rights of parents derive directly from the obligations of parents."7 This public statement was one or the earliest public acknowiedgments in Western Civilization that cilldren had personal rights separate from those of their parents. The need to protect children's rights in 
the United States was recognized in 1875 by the New York Soclety for the Prevention of Cruelty to Children, Ironicaliy eleven years after the American Soclety for the Prevention of Cruelty to Animals was created. 8

Contemporary soclety no longer approves parental power without qualification, even though in reality, there remain parents who behave as if no laws have been introduced. It is true that society's attitude toward the issue of children's versus parental rights has shifted a considerable distance; yet there remains a considerable amount of turmoll around this issue. A by-product of the aforementioned conflict over attitudes and values is the caseworker's reluctance to formulate predictive uniform criteria from which to measure parental abilities and potential and the unwillingness of courts to exercise their authority when protection of chlldren's rights is in question.

For many children, adoption and foster care constitute a necessary alternative to their otherwise chaotic, deprived lives. For the most part, these children come from families where social or emotional disorders of the parents are in some cases so severe as to permanently affect their parenting ability. The effects of these problems on the development of the children frequently result in infuries to the child's healthy psychosoclal development. 9 The 1959 C.W.I.A. Standards for Foster Family Care state that: 
Adoption should be considered as early as possible for children whose parents are, in all probabllity, unable or unwilling to meet the social responsibilities of adequate parenting; or when their whereabouts are un-

When adoption is neither desirable nor possible, foster fam11y care provides planned substitute family arrangements for children whose own families cannot care for them, elther on a temporary or extended basis. Furthermore, the standards state that the ultimate objectives of foster care, should be the "promotion of healthy personality development of the child and amelioration of problems which are personally or soclally destructive." 11 The following statistics seriously question whether current practice, in fact, actually achleves, these objectives. However, it should be noted that the standards still provide for the return of the child to his parents if their parenting capacity improves. The conflict in values thus again is apparent.

Since adoption is closest to normal family life it is consldered by the Child Welfare League Standards Commlttee as the best alternative, yet it affects less than one-third of the total number of children placed out of their homes annualiy. Two-thirds of the children living in slibstitute family arrangements were in foster homes or institutions. In 1967 a total of 200,000 children were reported to be in foster family care. ${ }^{12}$ Statistical estimates of the U.S. Children's Bureau foresee an Increase by 1975 to 364,000 
chllaren in foster homes or a rate of 4.7 chlldren in placement for every 1,000 children under age eighteen. 13 Jenkins reported that approximately one-half of all children entering initlal foster care placement remained for over three months, and a substantial number of these remained in care for much longer periods of time. ${ }^{14}$ Similarly, Maas and Engler found that most children were in care from two to flve years, averaging two to three placements, and that the longer they stayed, the less likely they were to be placed in a permanent home. In addition, about half of the children's parents had no plans for their future.15 In another study, Helen Stone reported that from forty-one to sixty per cent of children in care in 1969 would not be returning home in the foreseeable future. 16

In respect to what coula be called the current foster care "crisis," John Bowlby stated that:

Perhaps no chlld care practice has been more common or more damaging than that of agencles accepting children from "bad" parents on a temporary basis without a plan for their future. 17

In agreement with Bowlby's viewpoint are the reports from twenty-ive league member agencles from various parts of the country who state that hundreds upon hundreds of children are placed for indefinite perlods of time without any plan beyond thelr day by day care. Many agencles have aliowed such placements to arag along for years; although they have 
learned that every child, to develop normally, needs a dependable, continuing relationship. ${ }^{18}$ Perhaps most important of all, is that the likely duration of the foster situation is in many cases unknown; this adds to the uncertainty and hence, insecurity, inherent in the entire framework.

Uncertainty and insecurity are inimical to the building up and the growth of human relationships. If mutual trust is the basis for successful fostering, then success can be worked for and expected only when there is a measure of certainty and predictability in the situation. 19

Adults and children alike find uncertainty most disturbing. The indefiniteness which reflects the parent's uncertainty as to how much of a parent he can be, stands in the way of sound planning by the agency, and the foster parents as well. This indefiniteness is a major deterrent to foster parent applications. The possibility of losing the foster child prevents many families from applying who would otherwise be very capable foster parents. These famIlles will not take a child for an indefinite, temporary perlod, but are ready to apply for long-term or permanent care. ${ }^{20}$ If the extended nature of the arrangement is not established within a reasonable time, problem areas for foster parents may well develop, including insecurity vis-avis the child, hesitation about disciplining the child and host1ilty toward the natural parents. If placement is to be 
of real use to the child, the agency has no alternative but to help the parent come to some decision about his place in the IIfe of the child or to make the decision for him.

It should thus be apparent from the aforementioned statistics that the current practice is far removed from the orlginal 1dea of foster care which was to care for children whose parents were enveloped by a sudden crisis. Haltch reported that 46.5 per cent of the children in the foster care system are placed for such reasons as parental neglect, abuse or exploitation. 21 According to Haltch, foster care has changed drastically in concept from being largely a temporary home for displaced chlldren, to a service for the neglected.

It is becoming increasingly more important to differentlate long-term and permanent foster care from the original concept of temporary foster care. Currently, there is a lack of agreement within the Child Welfare Field as to what time period constitutes a short-term placement rather than a lorg-term placement. There are periods mentioned anywhere from three months, as proposed by Jenkins and Sauber, 22 to five years, as used by Parker in his description of the foster care system in Great Britain. 23 In more general terms, Madison and Shapiro define both long-term and permanent care as: 
- a period of care provided for a child on a planned basis when there is no foreseeable possibility of adoption or return to his home, and when extended care is the best casework plan for him. 24

The purpose of the placement in this case is to assure the child continulty of care and relationships through one set of parents who want him and intend to rear him. The difference between the terms "Iong-term" and "permanent" foster care lies in the legal status of the child. Long-term applies to the care of children who are in the physical custody of the agency but are not surrendered by their natural parents. Permanent foster care refers to those situations where parents have surrendered all rights to their children. The children become legal wards of the state with guardianship vested in the agency. The difference affects procedures in dealing with the situation of any particular child but not the fundamental substance of the arrangements. 25 In our study then, we are concerned with long-term care arrangements.

When children enter care because of family disorganization, it is often impossible at intake, or even after three months, to estimate length of stay. Some of these chilaren have no families to rejoin; others may experience a change in circumstances and be able to return home. Planning for these chlldren, however, needs to proceed for they cannot remain in limbo in the hope that they will all be re- 
claimed by their reconstituted families. Such planning needs to involve a choice of the most suitabie plan for care of each child and a prognostication at the point of intake as to the probable length of time in care.

A key factor then for planning services is knowledge of how long any child will remain in placement. Some estimate of length of placement can be made from knowing the total family situation. Jenkins for instance reported that the reason for placement was of particular relevance to estimating duration of care. In her study she classified reason for placement into five groups:

1. Physical 1liness or incapacity of child caring person.

2. Mental iliness of the mother.

3. Ferscnality or emotional problems of the child.

4. Severe neglect or abuse

5. Other family problems. 26

The length of time that a child is expected to remain in need of a foster home is of considerable importance both in the selection of a home and in the planning for supervision. The child expected to remain for a long period needs to be placed in a home where he can become a member of that family. He needs foster parents who can guide his development properly. Often special supervision and planning are needed to counteract the effects of prior experiences. Children expected to remain in foster care for only a few weeks or months, on the other hand, should be kept as close 
to their former background as possible. They can be placed In homes that one would not normally choose for a long-term placement. Once the initial short-term placement is properly handled, the supervision can be transferred to less experienced hands since the agency cannot expect to make much impact on a child's development in such a brief period. These then are only a few reasons which demonstrate the need for a reliable method of estimating the duration of foster care. Experienced workers must have guidelines of their own, but there has been surprisingly little effort to communicate these guidelines to others or to lay down general rules on the subject based upon predictive criteria. Recognizing the value of such guidelines in improving services delivered and decisions made, as to duration of care, we have attempted in our study to determine the feasibility of attempting to identify differences between families of chlldren placed in long and short-term care so as to ultimately develop predictive criteria which will then later perhaps, develop into agency guidelines. A description of our attempt follows, beginning with an explanation of the methodology and followed by a descriptive presentation of our results. The final section of our paper explains the Implications of our results as we see them. 
CHAPTER II: METHODOLOGY

\section{INTRODUCTION}

It was clear to the research group from the beginning that any attempt to differentiate between families of children in long and short-term care would be an exploratory venture designed primarily to determine the feasibility of a more comprehensive study as well as to gain insight into the problem. A comprehensive study would 1deally examine those areas of differences demonstrated through examination to be both identifiable and significant. For purposes of the study, it was decided a feasible method to contrast the families of children in long and short-term care would be to make an analysis of what has been referred to in the past as "Insight-stimulating examples."27 In other words, we would try to obtain cases exemplary of long and short-term foster family home placements. In this way we hoped to obtain exampies that provided sharp contrasts or had strikIng features. 28 since we did not want to select cases havIng small differences between them, but instead wanted "pure" cases on the extreme ends of a continuum of short to long-term foster care cases, we drew up the definitions of long and short-term care so that the difference in length of time in care would be magnified. At the same time the two groups were made as homogeneous as possible in many other 
respects as will be evident as selection criteria are examined. Once the two groups of cases were selected, we began looking at them in terms of a great number of characteristics later referred to as parental and family character1stics. All information was taken from the caserecords of the natural parents of the child or children who entered foster family home care. All cases used were drawn from the Clark County Washington Division of Public Assistance located in Vancouver, Washington. Furthermore, all cases contained chlldren who were placed in foster family care some time between July 1966 and December 1967.

What follows is a brief description of the agency and community from which the cases were drawn, a discussion of the caserecord as a source of information, a description of the way in which cases were selected, as well as a brief description of the two groups, and finally, a short discussion of how information was obtained from the records and subsequently analyzed.

\section{II: DESCRIPTION OF THE AGENCY AND COMMUNITY}

Clark County Washington Division of Public Assistance, part of the Washington State Department of Social and Health Services, is an agency which serves the needs of the 126,446 residents (estjmated as of the 1970 census count). 29 
The county ranks sixth in population among thirty-nine counties and has only 0.81 per cent non-whites residing within the county. 30 The clty of Vancouver, population estimated as of 1970 as forty thousand, is the county seat. 31 Since 1960, there has been an increase of about ten thousand persons living within the county. 32

Vancouver, Camas, Battleground, and Washougal, as major cities within the county are very much affected economically, culturally, and socially by the proximity of' Portland, Oregon, a major urban area which is just across the Columbia River from Vancouver. The known major employers in the county include the Alcoa Corporation and the Crown Zellerbach Corporation. There is some shipping in the area and spotty logging operations in the northern part of the county. Much of the population of the county (over onehalf) continues to live in unincorporated areas. Much of the area within the county contains a great deal of open farm land which is occasionally spotted by small dalry farms, many of which are now going out of business. Mid-1966 was used as a reference point to examine the agency itself. The child welfare services unit was then a separate unft having three supervisors and sixteen caseworkers. 33 Nine of the workers were listed simply as having child velrare services caseloads. The other workers had more specialized tasks. Included as workers havinz speclal- 
ized duties were a foster home finder, an adoption home finder, an intake worker, a protective service worker, etc. There were no persons concerned exclusively with foster care nor was there any specialization within the foster care caseloads.

Placement statistics available for the years 1966 to 1968 showed that there was only a slight change from year to year in the total foster care population. The monthly average of children between the ages of birth to eighteen years residing in Clark County foster homes was 416 for 1966, 394 for 1967 and 397 for 1968. It will become apparent from examining the long and short-term samples that they were extremely small, in number, compared to the total number of cases available for selection. Criteria used for case selection will be presented in another section within this chapter and are not noted here.

Finaliy, it should be noted that there were two other agencles in the county authorized to license foster homes and which had a purchase of care agreement with the Division of Public Assistance. These agencies were the Catholic Family Services Agency and Washington Chlldren's Home Society. Furthermore, reportedly it was common practice for cases to be referred to Catholic Family Services if the placing family wanted a Catholic family foster home. Many unwed mothers were referred to Washington Children's Home 
Soclety because at the time the Division of Public Assistance didn't have any speclalist to work with this particular client group. Catholic Family Services and Washington Children's Home Society had a relatively small number of foster family home cases compared to the Clark County D1v1sion of Public Assistance which was the main agency in the county providing foster care services at this time.

\section{III: LIMITATIONS OF USING CASERECORDS}

As was noted previously, information was taken strictiy from the caserecords. Leontine Young in her book, Wednesday's Chlidren, accurately describes some of the consequences of relying solely upon caserecords. She noted that the data recorded in the record was "secord-hand," recorded by many people, and limited by no specific outline. 34 . For our purposes, a comparison of cases was made more difflcult because of the absence of this specific outilne. Furthermore, when information was not recorded, it was frequently not clear as to whether this was due to the selectivity of the worker, the unavallability of the information or its non-applicability. In our study, we limited ourselves to reading the record of the natural parents to whom we later referred as either the parents or in some cases the "main-child caring person(s)." We found in the initial examination of cases that one could not always refer to the 
unit of analysis as a family or to the natural mother or father as parents simply because of the family disorganization. The records of the foster child and of the foster parents were not examined since our focus was upon the identification of the natural family characteristics prior to placement. The records selected were read only up to the time of placement so that the information recorded and analyzed was essentially the same that was avallable to the worker at the point of placement. This necessarily meant that the case material reviewed covered periods of varying lengths of time. One case might, for instance, have covered a perlod since 1960 even though the actual foster care placement took place in 1966. Another case might have only covered a period of one week. This had a definite effect upon all of our findings.

In using caserecords as the only source of information, one must remember that what is recorded can be more Indicative of the way a client responds to an agency (ultimately the worker being the agency) and perhaps less indicative at times of real life functioning. The interaction between client and worker as understood by the worker is what is recorded, thereby biasing to some degree the actual caserecord information. Perhaps it would have been wise to have developed a questionna1re and/or administered interviews in order to adjust for this bias. Ultimately, how- 
ever, 1t was not possible to utilize another method of data collection due not only to a shortage of funds but to a lack of time. Thus, it is likely that many of the more intangible aspects of the case that were not recorded may have been important. The results, then, can be no better than the records which provided the basic information.

IV: THE SELECTION PROCESS AND BRIEF DESCRIPTION OF CASES

Two groups of cases were drawn using the following guldelines. One group of cases was referred to as long-term cases. All the cases falling into this group had one or more chlld taken out of his home and placed in foster family home care for the first time between the period of July 1966 to December 1967 and with this child still in foster family home care as of July 1971. Other criteria for the long-term group included the child or children not returning home since the initial placement. Additionally, they were not Involved in any institutional care. It should be added that a case following the criteria mentioned above was examined, even if there were some children from this family returned home during this period of time. It was also examined even if not all of the children in the family were placed. In other words, if only one child was placed, the case was st1ll examined. This process was also used for the shortterm sroup. 
All of the cases defined as exemplary of a short-term placement were characterized by the situation where one or more child was taken from his home and placed in foster family home care for the first time between July 1966 to December 1967 for a period of three months or less and then returned to one or both of his parents. Importantly, the child(ren) under consideration must have then not reentered substitute care for a minimum of three and one-half years. As in the long-term group, institutional care would eliminate the case from the sample.

The criterla used in selecting these two groups were derived from a number of important considerations. The specifled time span was selected in part because we wanted the cases drawn to be free of any sampling bias which might be expected to occur if the case were drawn during a given month or quarter. It was known, for example, that the number of placements in a given year tended to increase sharply in the winter and decrease in the summer. We realize that by using this time span, none of the children in the long-term foster care arrangements could have been more than fourteen and one-half years old when they were placed; otherwise, thelr case would have been closed as of July 1971. Thus, in selecting short-term care cases, we elimInated any case where there was not at least one placed child who was fourteen and one-half or less. This elimina- 
tion was of course another limitation to the study and thus the adolescent aspects of the subst1tute care problem were to some extent not dealt with and the sample further decreased in size. Secondly, since the cases were drawn from the same period of time, it was hoped that they would be subject to the same agency policies, handled by essentlally the same workers, etc. Third, using the criterla mentioned, we very specifically eliminated cases where the following situations prevailed: (1) the teenager who ran away from home, seeking foster care for a varlety of reasons that may or may not have been indicative of the parents' parenting ab1l1ty, (2) the child who may have had several foster home placements over a span of time with intermittent returns home, (3) the child who may have been placed in an institution for reasons of retardation, physical difficulties, or soclal misconduct, (4) the child who had elther been voluntarily relinquished or removed from parental custody by a court and placed immediately for adoption. Consequently, it was not always possible to account for many independent varlables, resulting from the selection process 1tself, which may have affected our findings.

A further ramification was that by limiting the longterm cases to those where the child(ren) was not returned to his home within three and one-half years, we hoped to end up with cases most characteristic of the long-term care sit- 
uation in which the child remains in care indefinitely without much liklihood of ever being returned to his parents. Finally, by limiting the short-term cases to those where once the child was returned home, he remained out of any type of substitute care arrangement for at least three and one-half years, it was hoped that we would obtain those cases most exemplary of a short-term care arrangement where care is needed essentially on a temporary basis for a short period of time and is not part of a pattern where a child "bounces" over a period of a few years from his own home to that of the foster parents. The only indications which assured that a child had not re-entered a substitute care arrangement in another location was that if he had gone back Into care within Washington state, there would have been an administrative transfer of records. If he had re-entered care in another state, it was assumed that record on file would have contained a summary sent to the agency involved. In using the criteria outilned above, we found six long-term care cases. Eleven short-term care cases fit our criteria and since we wanted an equal number to the longterm cases, six of the eleven were drawn by numbering the cases from one to eleven and then drawing out six numbers. The long-term cases were made up of six families containing thirty-one children. Out of this group of children in the home at the time of placement, sixteen children were placed 
during the dates under consideration. In all cases it was easy to 1dentify the mother who was in most cases the "mainchild caring person." In several of the cases, it was difficult to identify the father who was most important to the family. There were a number of instances where the father mentioned in the record was not particularly the significant flgure at the time of placement. The short-term cases were made up of six families contalning elghteen children living at home. Out of this group of children, sixteen were placed on the dates referred to as the initial dates of placement. Because of the manner in which the cases were selected, it was evident that the children placed were not representative of the total spectrum of foster care cases but instead representative of long and short-term care as defined above. It is interesting to note that only six long-term cases fit our criteria exactly. This is explained in part by noting that the criteria for selection of cases were narrowly drawn, as we were concerned with choosing extremes in short and long-term care placements in order to better Identify differences between the two groups.

\section{V: THE PROCESS OF DATA COLLECTION AND ANALYSIS}

All flve members of our group began by reading each of the selected long and short-term cases. Initially each was reac without any preconceived notions as to what exactly 
we were looking for. At this point, each member of the group tried to record what he feIt to be significant. We soon discovered that most long-term cases had been opened for a comparatively longer period of time and therefore took a longer period of time to read than the short-term cases. Once all of the members of the group had read the twelve cases, we began discussing each case individually, taking the long-tern cases first and then the short-term group. Each member had the responsibility for a final written product which contained the information on one long and one short-term case, with one person in the group responsible for two cases. The written product was a synopsis of information collected in various areas by all group members. Cases were first discussed in terms of information found in specific areas referred to basically as parental and family characteristics. Below is a list of these characteristics:

\section{Parental Characteristics}

Birthplace of parents

Age of parents at placement

Age of parents at marriage

Number of legally initiated marriages

Number of separations

Marital status at time of piacement

Education of parents

Employment

Physlcal health of parents

Mental health of parents

Caseworker's perception of parents

Developmental history

Alcohol - Drugs

Arrest - Confinement

Military service

Religion 
Family Characteristics

Number of chlldren in home at placement

Total number of living chlldren

Number of children placed out of total at home at time of placement

Families having provided out-of-home care to children previous to placement

Age of children at placement

Parental attitudes toward children

Parent-child relationships

Children's functioning

Housing

Hou sekeeping

Family financial situation

Extended family and friends

Length of prior contact with Public Assistance

Protective Services unit involvement

Community agencies involved

Voluntary/involuntary placement and complaints

Reason for placement

It should be noted that it was not known in advance what areas would be found to be significant or what areas would include little or no information. Importantly, this was one of the objectives of our study. The development of our checklist containing areas for examination was again a group product evolving from our discussion of what the records contained as well as derived from our individual reading of the avallable literature.

There were several advantages to developing a checkIist after reading the records. First, it meant that we would not begin to read the records selectively in terms of a limited amount of variables which might prove later to be of no significance and overlook possible significant data. Second, we had no ldea in advance, as to the quantity or 
quality of information available in the records. In developing the list in retrospect, we were then tied to what was avallable in the records themselves. Accordingly, gaps or unavailable information in the records had relevance in. 1tself. For instance, almost immediately we found that there was little information on the childhocd experiences of the parents (referred to as the developmental history), yet we suspected that this was an area of major importance in determining the duration of the foster care placement. There was an assumption made by the group members that one could look at the records and reccrd what he thought to be significant without an initial checklist, simply because there were four other persons doing somewhat the same thing. Heavy reliance was put upon the fact that we were achleving as a group what would perhaps not be feasible as individuals. This would tend to diminish individual bias in what was considered significant characteristics.

Once composite plctures were agreed upon for all the cases under consideration spanning the wide number of areas examined, we again began as a group to analyze the data noting both similarities and differences among and between the two groups. To reiterate, this feasibility study was an attempt to determine availability of information from case review, which would suggest significant differences and identiflable patterns sufficlent to lend themselves to a 
further predictive study. We also hoped to develop our own insight into the differences between families of children In long and short-term care. What follows in the next chapter is the presentation of our findings. 
CHAPTER III: RESULTS

\section{INTRODUCTION}

In this chapter we will present the results of our examination of the long and short-term case records. The chapter is divided into three sections, beginning with an introduction which includes two brief narratives that represent the two basic types of case records studied. The second portion of this chapter examines our findings around the Individual characteristics of the parents, while the final portion deals with those characteristics that seem to be related to the family as a unit. The implications of these results will be further examined in the final chapter.

Case Examples:

Mr. and Mrs. Barker 35

Mr. and Mrs. Barker, whose children remained in care well over three years, were married in 1955, and remained together at the time of placement in 1967, although there had been many separations during their marital history.

Mr. Barker was born in 1934 in North Dakota, and completed the eleventh grade. This is his only marriage. He Is usually employed as a truck driver or mill worker, although he is known to have done farm labor many years aso. He has helo many different jobs, none lasting more than six months. His physical appearance has never been noted, but he has been described as passive and uninvolved. He lets 
his wife deal with the caseworkers, and he seems to maintain a passive role toward his children except when they get into his things for which he beats them. The school psychologist says he has minimal effect. He has a stomach ulcer, and sustained a back injury on-the-job for which he wore a back brace for a time. He was jalled at one time for sexually molesting a nine year old girl, and has a drinking problem for which he has been hospltalized. He was arrested after a car accident in 1958, and lost his driver's license for a time. He served in the army from January 1953 to october 1954, and was granted an honorable discharge. No history has ever been gained around Mr. Barker's development as a child.

Mrs. Barker was born in 1935 in Portland, completed the elghth grade, and lists her religion as protestant. She was married once prior to her current marriage, in 1952, but no children were born of this union. She has no known employment history. She is described as obese, and at the time of first contact in 1964 she was seen as distracted, nervous, and susceptible to suggestion. In 1966 she seemed depressed, in April of 1967 she appeared docile and submissive. She has no known health problems, she says she needs a psychlatrist, and talks about having hallucinations. She has attended the mental health clinic briefly in the past when particularly depressed. She has no problems with alco- 
hol or drugs, and has never been arrested. Her parental family has been recelving public assistance in Clark County for many years, where her siblings were in foster care. She was never placed, but remalned at home, where she was molested by her father, until her marriage at age seventeen. She relates that her children get on her nerves, and expresses ambivalence, rejection, and guilt toward them.

The Barkers have had a long history of money problems, including going through debtors court. At the time of the children's placement, they were renting a house which was described as disordered, dirty, and in 111 repair. They have moved a great deal, particularly when Mr. Barker has been out of the home. At these times of separation, Mrs. Barker and the children have gone to stay with varlous relatives and friends.

There is much contact by the Barkers with Mrs. Barker's famlly, who have often cared for the Barker children. Mr. Barker's parents have often taken him back into their home, although they have been less involved with Mrs. Barker and the children.

There have been four children born to this marriage. Susan, born September 10, 1958, at placement was having problems in school, including having to repeat the first grade. She was seen to be a slow learner, and seemed to carry much responstbility at home. John, born September 15, 
1959, was seen as bright and 1nquisitive, and upset by the foster home placement. George, born March 14, 1966, was hyperactive, born prematurely and very 11l. Brian, born August 1, 1967, was alert and healthy, and an easy delivery. This family has been known to Clark County welfare since May 1964 when Mrs. Barker requested financial assistance for herself and the children, saying that she had separated from Mr. Barker and was seeking a divorce. She requested her case closed in June 1964, but then returned in July for further help. This case was closed in October 1965, but reopened in September 1966 in Protective Services due to many complaints from neighbors concerning the care of the children.

The Barker children were placed in foster care in September 1967 after Mrs. Barker attempted sulcide and was admitted to the hospital. Mr. Barker requested public assistance for the chlldren, but this was denied. He then requested foster home placement. Upon Mrs. Barker's release from the hospital, the eldest children were returned to her where they remained for three weeks. She then returned them to care sayling that she was unable to handle the responsibility. From this time, the four Barker children remained in care continuously. 
Mr. and Mrs. Johnson

Mr. and Mrs. Johnson, whose children were in care for three weeks were each married for the first time on May 10, 1962, although they are now separated and have flled for divorce.

Mr. Johnson, born February 24, 1933 in New York, completed the twelfth grade and has been steadily employed for the last four years with Civil Service in the Department of Fisheries. There is no physical description of Mr. Johnson, but he is described by his wife as sincere, quiet, and interested in their children. He has no known physical or mental problems. Mrs. Johnson relates that her husband does have a drinking problem, which precipltated their separation, although he has never been arrested for this and is able to maintain his employment. No information is avallable around his development, although it is known that he entered the navy in November 1959. His length of military service and discharge status are unknown. Since the Johnson's separation in August 1966, Mr. Johnson has pald child support and has continued medical coverage for the children.

Mrs. Johnson, born December 3, 1936 in Idaho, completed the eleventh grade and indicated that she is Baptist. She has been employed seasonally in the past as a cannery worker. She is described as thin and tired, but well groomed. She seems to be a methodical thinker who gives 
answers slowly. She indicates interest and motivation for employment training. She is a diabetic, and was hospital1zed in 1965 for a diabetic reaction. She has no known mental problems, and there is no indication of difficulty with alcohol or drugs. She descrlbes her background as deprived, saying that her parents are divorced. She indicates that both of them had drinking problems, and she was beaten on occasion by her stepfather. She seems to have a good relationship with her children. She talks about them and her responsibilities toward them.

At the time of the Johnson's separation; Mrs. Johnson moved herself and the children into the home of an aunt on a temporary basis. There have been two additional moves since that time, and at this time of placement, she is renting a rundown apartment that is described as cluttered, but clean with nicknacks around.

There were two children born of the Johnson's marriage. Mrs. Johnson was pregnant at the time of her marrlage, and Lisa was born on June 1, 1962. Lisa seems to like school and is doing average work. Julle was born on February 1I, 1964, and she as well as IIsa, expresses much concern and affection for both her parents.

The Johnsons have been known to Clark County since August 1966, when Mrs. Johnson requested financial assistance due to her recent separation. Although Mr. Johnson has 
been regular in his support, and there are no known financial difficulties, Mrs. Johnson has been in need of supplementary financial assistance since that time to maintain herself and the children. There have been a few complaints recelved from a neighbor concerning Mrs. Johnson's having men in her home.

On November 17, $1966 \mathrm{Mrs}$. Johnson requested foster care as she was 111 and in need of hospitalization. She was referred by her caseworker to the Juvenile Court for this. The chlldren were placed with a nelghbor overnight, and then came into care the next day where they remained for three weeks until Mrs. Johnson was sufficiently recuperated to resume care of them.

\section{PARENTAL CHARACTERISTICS}

\section{Birthplace of Parents}

We noted that only four of the twenty-two persons whose birthplace was known were born in the state where they now reside. This was equally true of both long and short term cases and there was no way of distinguishing between the two types of cases on the basis of birthplace. We did not locate hard data to compare our findings, but Jenkins did find "a substantial amount of mobility in the family background of chlldren placed in foster care reflected in the birthplace information when compared with the current resi- 
dence." 36 She concluded that the absence of an established extended family close at hand may have contributed to the problems of securing help with the child care in crisis situations. From our findings we would add that the quality of the relationship with extended family and friends was a deciding factor when the decision to place was made.

TABLE I

BIRTHPLACE OF PARENTS

\begin{tabular}{lll}
\hline \hline & L.T. & S.T.* \\
\hline $\begin{array}{l}\text { Mother } \\
\text { Within State }\end{array}$ & 2 & 1 \\
Out of State & 4 & 5 \\
Father & & \\
W1thin State & 1 & 0 \\
Out of State & 4 & 5 \\
Unknown & 1 & 1 \\
\hline
\end{tabular}

*The symbols "L.T." used in the Tables represent "long-term," and "S.T." means "shortterm."

Age of Parents at Placement

Because of the limited sample, the somewhat older age of the long-term parents is not statistically significant by 1tself. We also found that case number four long-term tends to distort the statistical average toward elderliness while case number four short-term distorts toward youthfulness. 
TABLE II

AGE OF PARENTS AT PLACEMENT

\begin{tabular}{|c|c|c|c|c|c|c|c|}
\hline & \multicolumn{6}{|c|}{ Case Number } & \multirow[b]{2}{*}{ Ave. } \\
\hline & 1 & 2 & 3 & 4 & 5 & 6 & \\
\hline $\begin{array}{l}\text { L.T. } \\
\text { Mother } \\
\text { Father }\end{array}$ & $\begin{array}{l}30 \\
31\end{array}$ & $\begin{array}{l}25 \\
28\end{array}$ & $\begin{array}{l}34 \\
33\end{array}$ & $\begin{array}{l}44 \\
60\end{array}$ & $\begin{array}{l}22 \\
43\end{array}$ & $\begin{array}{l}25 \\
31\end{array}$ & $\begin{array}{l}30 \\
38\end{array}$ \\
\hline $\begin{array}{l}\text { S.T. } \\
\text { Mother } \\
\text { Father }\end{array}$ & $\begin{array}{l}30 \\
34\end{array}$ & $\begin{array}{l}22 \\
31\end{array}$ & $\begin{array}{l}29 \\
28\end{array}$ & $\begin{array}{l}17 \\
18\end{array}$ & $\begin{array}{l}33 \\
41\end{array}$ & $\begin{array}{l}30 \\
37\end{array}$ & $\begin{array}{l}27 \\
30\end{array}$ \\
\hline
\end{tabular}

This study does, however, tend to confirm Murphy's findings in his article "predicting Duration of Foster Care" where he found that the age of the mother at placement makes a difference in whether the child placed in foster care returns to his home.

The proportion of children requiring long-term care increased for mothers in their early twenties, decreasing to a very low flgure for mothers in their early thirties and then increasing again as mothers approach forty. 37

We found that the age of long-term mothers generaliy followed this pattern with three cases where mother was in her "early twenties" and two cases where mother was in her "late thirties approaching forty." Only one case broke this pattern. Similarly, the short-term cases followed a pattern with a high incidence of mothers' ages in or around "early thirties." one short-term mother was seventeen and did not f1t in any of Murphy's categories while the other case broke 
the pattern and fell into an otherwise long-term placement age category. In summary, Murphy's observation is upheld in this study and the mothers' age helps provide an indicator that distingulshes long and short-term foster care results. 4
3
2
1
0

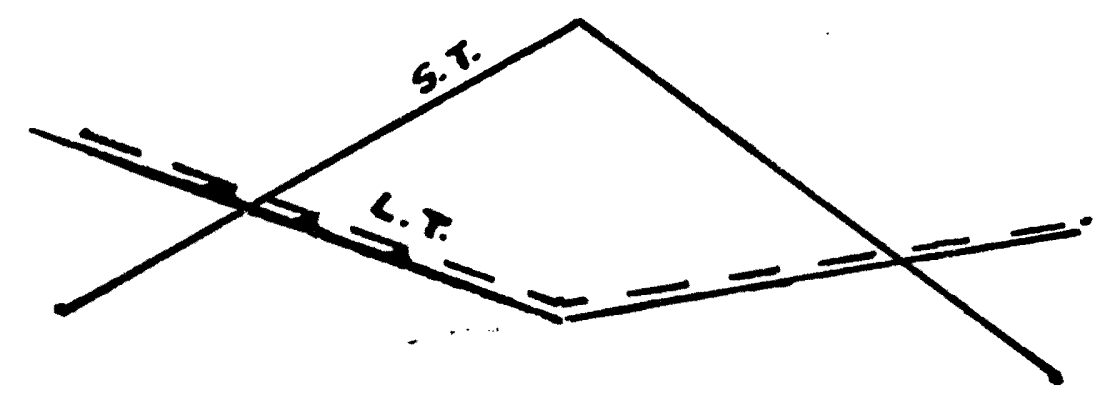

Late 20 's Early $30^{\prime} \mathrm{s}$ $(27-33)$
Late 30 's Early $40^{\prime} \mathrm{s}$ $(34-40+)$

FIGURE 1

AGE OF MOTHERS AT PLACEMENT MURPHY'S PATTERN

Age of Parents at Marriage

Our study examined the age of the parents at the time they married their current spouse. Table III shows that the short-term mothers married on an average two years younger (short-term 19; long-term 21) than the long-term mothers. The short-term fathers averaged five years younger (shortterm 24; long-term 29) than the1r long-term counterparts. Because of the problem of extremes, there were limitations to the statistical average, and, therefore, we subtracted the high and low age of the mother and father in both 
groups. In this process the difference between the ages of short-term and long-term mothers was reduced to less than a year (short-term 18.75; long-term 19.5). For the fathers when the high and low age was subtracted, the difference was reduced to slightly more than a year (short-term 24.25; long-term 25.5). Thus, the ages at marrlage for the mothers and fathers of long-term and short-term placements shows 11ttle difference and by itself does not distinguish longterm and short-term cases.

TABLE III

AGE OF PARENTS AT MARRIAGE

\begin{tabular}{llllllll}
\hline & \multicolumn{8}{c}{ Case Number } \\
\cline { 2 - 6 } & 1 & 2 & 3 & 4 & 5 & 6 & Ave. \\
\hline L.T. & & & & & & & \\
Mother & 19 & 16 & 23 & 37 & 20 & 13 & 21 \\
Father & 20 & 19 & 22 & 52 & 41 & 19 & 29 \\
S.T. & & & & & & & \\
Mother & 25 & 20 & 22 & 16 & 16 & 17 & 19 \\
Father & 29 & 28 & 21 & 17 & 24 & 24 & 24 \\
\hline
\end{tabular}

The study results show that the long-term marriage partners average eight years difference in their ages (mother 21; father 29) while the short-term partners average flve years difference (mother 19; father 24). The difference between the two groups is most reflected in two long-term 
cases (case numbers four and five) where the difference was fifteen and twenty-one years. By subtracting the two cases of greatest difference in both long-term and short-term cases the difference between long-term marriage partners was reduced to 2.25 years and for short-term, 2.75 years. Where before the short-term males averaged three years closer to the age of their wives, by subtracting the extremes, the long-term males were shown to be closer to their wives than their short-term counterparts. Thus, the difference in age between marital partners does not appear to be significantly different for long-term and short-term cases nor does it distinguish between these two type of cases.

Number of Legally Initiated Marriages

Our findings show that four of the twelve marriage partners in long-term cases had more than one legal marriage. Only one of the twelve marriage partners among short-term cases had more than one marriage. Since face sheet information had been completed thoroughly on both long-term and short-term cases, we concluded that the records would be equally valid reflections of past marital history. In addition, because the parents in both categorles are of similar age, we can conclude that they have had an equal opportunity to have experienced multiple marriages. It is sometimes questioned if divorce is an equal opportunity for the less 
economically stable (long-term), but from our study it would seem that it is. The long-term families have apparently used divorce as a way out in the past when marriage problems have developed. It should be kept in mind that it would be unlikely that common law marriages could be analyzed (only one was reported) since such a statement would automatically make a person ineligible for public assistance in the State of Washington.

TABLE IV

NUMBER OF MARRIAGES

\begin{tabular}{llllllll}
\hline & \multicolumn{7}{c}{ Case Number } \\
\cline { 2 - 7 } & 1 & 2 & 3 & 4 & 5 & 6 \\
\hline I.T. & & & & & & \\
Mother & 1 & 1 & 2 & 3 & 2 & 1 \\
Father & 1 & 1 & 1 & 1 & 2 & 1 \\
S.T. & & & & & & \\
Mother & 1 & 2 & 1 & 1 & 1 & 1 \\
Father & 1 & 1 & 1 & 1 & 1 & 1 \\
\hline
\end{tabular}

Number of Separations

When examining the number of separations we found great difficulty comparing short-term and long-term categories. The long-term cases had much longer contact with the agency and the recording of separations related clearly to the length of time a caseworker was in contact with the 
family. We were somewhat surprised that in three of the long-term placements no separations were noted, and in two of the three cases where separations occurred, incarceration was the principle reason/cause of the separation. At the same time, we noted in the previous section that divorce was used more frequently by long-term cases in the past for solving marital difficulties. In general then, there were no more separations among long-term families than short-term and in actuality, the decision to separate (at the time of placement) was used more frequently among short-term cases. This relates clearly to the marital status at the time of placement where short-term families were predominately separated while five of six long-term families considered themselves married and living together.

This ralses the question of the meaning of separation and reconciliation. We have no data from which to draw a conclusion, but we did note that even in case number three (long-term) there was no consclous planned decision to separate and we speculate that dependency needs of both marital partners brought them repeatedly back together. Maas and Engler's study in Westport shares our Impressions; for they found that more mothers (thirty-three per cent) were married and living with their spouse among cases where children were not retusned than in cases where children returned to the family (only twenty-five percent were living with spouse.) ${ }^{38}$ 
TABLE V

NUMBER OF SEPARATIONS

\begin{tabular}{lllllll}
\hline & \multicolumn{7}{c}{ Case Number } \\
\cline { 2 - 7 } & 1 & 2 & 3 & 4 & 5 & 6 \\
\hline L.T. & 0 & $7^{*}$ & 5 & 0 & 0 & $2^{* *}$ \\
S.T. & $3^{* * *}$ & 0 & 1 & 0 & 2 & 1 \\
\hline
\end{tabular}

* 5 due to incarceration.

* 1 due to incarceration.

*** 3 due to incarceration.

Marital Status at Time of Placement

Marital status at time of placement is based on how they, the parents, saw themselves when the child(ren) was placed in care. Our findings reveal that only one of the short-term mothers was married and living together with her spouse at placement. In contrast, five of the six longterm mothers considered themselves married and living with their spouse. In addition, even though separated because of incarcertaion, the sixth long-term case considered that her family was intact. Combined with the question, we were impressed by the long-term mothers'inability to make a decision concerning separation. They frequently described problems and made complaints that caused them to think about and consider separation. Though they talked of the plan with the caseworker, they were unable to make the separation 
even though their clrcumstarces were at least as difficult as the short-term cases. It was as if they were psychologically married and irreversibly tied to one another's symbiotic needs. We make this statement recognizing that multiple marriages were more frequent in long-term cases, but also aware that at the time of placement the long-term families were 1mmobilized in their apparent inability to plan for change.

TABLE VI

MARITAL STATUS AT PLACEMENT

\begin{tabular}{lcc}
\hline & L.T. & S.T. \\
\hline Married and Together & 5 & 1 \\
Separated & 1 & 4 \\
Divorced & 0 & 1 \\
\hline
\end{tabular}

Education of Parents

The education level of the parents was examined based upon the last recorded grade completed in school. We found a pronounced difierence in the amount of information avallable on this subject. Information was available on only four of the six long-term cases. We compared the number of persons in both groups who were high school graduates and found that only one of elght persons in long-term cases, where information was avallable, was a high school graduate. 
For short-term cases, four of the twelve persons had a high school diploma. Taking the percentage of known cases, sixteen per cent of the long-term cases had a high school diploma while thirty-three per cent of the short-term ind1viduals had a high school diploma.

TABLE VII

EDUCATION OF PARENTS

\begin{tabular}{lrrrrrrrr}
\hline & \multicolumn{7}{c}{ Case Number } \\
\cline { 2 - 6 } & 1 & 2 & 3 & 4 & 5 & 6 & Ave. \\
\hline L.T. & & & & & & & \\
$\begin{array}{c}\text { Mother } \\
\text { Father }\end{array}$ & Unk. & 8 & 7 & Unk. & 10 & Unk. & 9.5 \\
S.T. & 12 & 10 & 9 & Unk. & 10 & 11 & \\
$\begin{array}{c}\text { Mother } \\
\text { Father }\end{array}$ & 14 & 10 & 8 & 9 & 9 & 11 & 10.1 \\
& 12 & 9 & 12 & 10 & 16 & 7 & \\
\hline
\end{tabular}

We compared the educational achievement of the mothers and fathers in long-term and short-term families. We discovered that three of the six short-term mothers had equal or higher education than their husbands. Of the three long-term mothers where complete information was avallable to make a comparison, none of the mothers had a higher and only one had equal education of husband. We suggest that this relates to the employability of short-term women as described in the next section and when combined with the financial plcture for the family (much less dependence upon 
public assistance) suggests a somewhat greater potential for self sufficlency and maintenance of an independent living situation among short-term women.

Employment

The employment history of long-term and short-term mothers and fathers was examined. The results indicated that the short-term mothers had more employment experience. We found less difference between long-term and short-term fathers which was measured in terms of steady, sporadic or no employment. The tendency toward employability for shortterm mothers would tend to compare with their pattern of Independent living arrangement when family problems resulted in pressure to separate. Employability also relates to factors of education and motivation that were prevalent among short-term mothers. The difference appears valid since due to the nature of the long-term cases, they have had longer contact with the agency and it could be anticlpated that there would be a greater reference to employment for this group if it were true. At the same time, these results cannot be generalized too far since in all but one case the initial contact with the agency was for financlal reasons and only secondarlly for foster care. Other agencles offering foster care service without financial assistance might not be comparable. 
TABLE VIII

EMPLOYMENT

\begin{tabular}{lcc}
\hline & L.T. & S.T. \\
\hline $\begin{array}{l}\text { Mothers } \\
\text { Some* } \\
\text { None }\end{array}$ & 2 & 4 \\
$\begin{array}{l}\text { Fathers } \\
\text { Steady } \\
\text { Sporadic } \\
\text { None }\end{array}$ & 4 & 2 \\
& & \\
& 3 & 4 \\
* Includes babysitting and berry \\
plcking. \\
** Disabled. \\
D* Incarcerated time of placement.
\end{tabular}

As the employment history was analyzed, it was concluded that the types of employment required about the same kinds of skill for both long-term and short-term jobs held. We noted that job switching was slightly more prevalent among long-term cases, but in general, and particularly tor men, the employment picture was very similar for both longterm and short-term cases. 
Physical Health of Parents

The physical health of the long-term and short-term parents was examined in terms of whether the individual parent considered himself to be suffering from a health problem. The results show that for the mothers, health was more a problem in the short-term cases and in three of the six cases 111 health related very directly to the reason for placement. In addition, health problems for the shortterm mothers reflected a crisis situation while health problems for long-term mothers were of a chronic nature and in no case was 11 lness the principal reason for placement. In summary, the health problems of the short-term mothers was more debilitating and reflected a crisis situation as three of these short-term mothers required hospitalization.

For the fathers, long-term cases showed the greatest number of problems. Four of the long-term fathers complained of health problems while only one of the short-term fathers mentioned physical health as a problem. In general, the health problems of the long-term fathers was more debilitatIng as two cases required surgeries and in one of these cases, four surgeries. The one instance of a health problem in the short-term cases (where the father sustained a back infury as a result of a car accident) surgery was not 
required and he returned to employment without a lengthy period of recuperation.

The significance of illness as a factor in foster

placement is demonstrated by Jenkins who discovered a

sharp increase in the percentage of familles with 1llness at the time of placement over those with illness a year prior to placement. Only 25\% of the families had an adult member who was ill the year prior, but 48\% had an 111 adult at the time of placement. When including children, only $27 \%$ of the families reported all family members in good health. 39

The significance of 11 lness will be further examined under the heading "Reason for Placement."

TABLE IX

PHYSICAL HEALTH OF PARENTS

\section{L.T. S.T.}

\section{Mothers}

Recorded Problems

None Recorded

$3^{*} \quad 5^{* *}$

Fathers

Recorded Problems

None Recorded

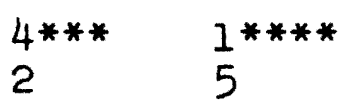

Examples:

* "Chronic Tonsilitis," "Severe Arthritis,"

"Asthma."

* "Strabismus and Walking Deformity " "Cysts, Miscarriages and Yeast Infection," "Acute Pneumonitis, Vaginitis, Anemia, Spastic Stomach, Kidney Infection and Miscarriages," "Dlabetic," "Bursitis."

** "Removal of Lung and Pleurisy of Spine," "Stomach Ulcer and Back Infury," "Hypertension and Heart Trouble."

*** "Back Injury." 
Mental Health of Parents

Mental health was recorded in terms of complaints by the parent that emotional problems were interfering with the family/individual functioning. For both mothers and fathers, the long-term cases showed a significant preponderance of recorded emotional problems. Together, nine of the twelve long-term parents recorded emotional problems while only three of the twelve short-term parents recorded emotional problems.

of the mothers, two of the long-term cases required hospitalization in a state institution with one case preclpitated by a suicide attempt. A third case attended outpatient mental health services for "depression and hallucinations." A fourth case included a mother using tranquilizers to maintain herself and a fifth case included an assessment of the mothering suffering with "severe anxiety." In one case there was no recorded emotional problem. The short-term cases included one mother who attempted sulcide by over-dosing. Another mother complained of generalized symptoms of "panic, dizziness and breathing difficulty." A third mother was assessed as being unable to accept her diabetes and her resulting hospitalization was speculatively seen as a suicide gesture. In three cases there were no comments or complaints indicating emotional disorder. 
Comparatively, two long-term mothers required inst1tutionalization while none of the short-term mothers were seen to need this. We conclude that the long-term conditions were generally more chronic and the origins have a longer history while short-term conditions appeared more situational.

For the fathers there was an even greater variance between long-term and short-term cases. None of the shortterm records indicated that the fathers suffered handicapping emotional problems. Four of the long-term fathers, however, appeared to have serlous problems. One of the fathers (long-term) was hospitalized (self committed) for thirty days. Two fathers were found guilty of child molestation (one was tried in court and convicted while the other was substantlated when the child entered foster care, but legal action was not taken). A fourth long-term case was difficult to assess but his pattern of wandering in and out of the family home was considered handicapping to the family and seen as disturbed emotional health. Two long-term cases suggested no symptoms of emotional disturbance. 
TABLE X

MENTAL HEALTH OF PARENTS

\begin{tabular}{lll}
\hline & L.T. & S.T. \\
\hline Mothers & & \\
$\quad$ Recorded Problems & 5 & 3 \\
$\quad$ None Recorded & 1 & 3 \\
Fathers & & \\
$\quad$ Recorded Problems & 4 & 0 \\
$\quad$ None Recorded & 2 & 6 \\
\hline
\end{tabular}

Caseworker's Perception of the Parents

A consplcuous feature of casework recording is the assessment by the worker of the client's current functioning In a varlety of areas. Our twelve cases were examined to extract positive and negative statements made by the workers in describing the functioning of the parents. In some cases where there was a change of caseworker, the assessment includes more than one worker's assessment. Scoring for Table XI is based on the caseworker's written description or assessment of the parent(s) in four areas: physical appearance, affect, parent (child) relationship, and home cond1tion. We recorded the positive negative descriptions used by the worker to come up with a score for both mothers and fathers in all four categories for both long-term and shortterm cases. The given score does not represent a net value. 
between cases, but generally reflects a preponderance of elther positive or negative worker perceptions. In cases where there were both positive and negative references a combination score was given.

To obtain the combined general impression we subtracted positive statements from negative statements and found a total of sixty-five negative statements for longterm cases against two negative statements combined for the short-term cases. The greatest single difference was between long-term and short-term mothers in the category of "Affect." Again, the specific numerical score is not so significant as the comparative breadth of the spread between the long-term and short-term cases. We concluae that the worker's perception/assessment was clearly recorded In more positive statements for the short-term cases. We are unable to speculate on the specific role the worker played that might have influenced whether a case became long-term or short-term, but the results suggest a close relationship between the caseworker's perception of a case and the duration of foster care. 
TABLE XI

CASEWORKER'S PERCEPTION :

POSITIVE V. NEGATIVE STATEMENTS

\begin{tabular}{|c|c|c|c|c|c|c|c|}
\hline \multirow[b]{2}{*}{ L.T. } & \multicolumn{2}{|c|}{$\begin{array}{l}\text { Physical } \\
\text { Appearance }\end{array}$} & \multicolumn{2}{|c|}{ Affect } & \multicolumn{2}{|c|}{$\begin{array}{l}\text { Parent-Child } 3 \\
\text { Relationship }\end{array}$} & \multirow{2}{*}{$\begin{array}{l}\text { Home } \\
\text { Cond1- } \\
\text { t1on }\end{array}$} \\
\hline & Mo. & $\mathrm{Fa}$. & Mo. & $\mathrm{Fa}$. & Mo. & Fa. & \\
\hline $\begin{array}{c}1 \\
2 \\
3 \\
4 \\
5 \\
6 \\
\text { Total } \\
(-65) \\
\end{array}$ & $\begin{array}{r}0 \\
0 \\
-1 \\
-2 \\
-3 \\
0\end{array}$ & $\begin{array}{r}0 \\
0 \\
0 \\
-2 \\
0 \\
0\end{array}$ & $\begin{array}{l}-1 \\
-9 \\
-4 \\
0 \\
-3 \\
-3\end{array}$ & $\begin{array}{r}-1 \\
-5 \\
-5 \\
0 \\
0 \\
-3\end{array}$ & $\begin{array}{r}0 \\
0 \\
-1 \\
-2 \\
-2 \\
-1\end{array}$ & $\begin{array}{l}-1 \\
-1 \\
-1 \\
-2 \\
-1 \\
-1\end{array}$ & $\begin{array}{c}0 \\
+1 /-2^{*} \\
-4 \\
-1 \\
-4 \\
+1 /-1\end{array}$ \\
\hline \multicolumn{8}{|l|}{ S.T. } \\
\hline $\begin{array}{c}1 \\
2 \\
3 \\
4 \\
5 \\
6 \\
\text { Total } \\
(-2)\end{array}$ & $\begin{array}{r}-1 /+1 \\
\pm 1 \\
0 \\
-2 \\
-3 /+3 \\
-2 / \pm 1\end{array}$ & $\begin{array}{l}0 \\
0 \\
0 \\
0 \\
0 \\
0\end{array}$ & $\begin{array}{r}+3 /-1 \\
-4 \\
+3 /-2 \\
0 \\
+2 /-1 \\
+2 /-2\end{array}$ & $\begin{array}{r}0 \\
-2 \\
+1 /-3 \\
+2 \\
+2 / \pm-1 \\
+1\end{array}$ & $\begin{array}{r}+1 \\
\pm 1 \\
+1 \\
+1 \\
+1 /-1 \\
+1 /-1\end{array}$ & $\begin{array}{r}0 \\
+1 \\
+1 \\
+1 \\
+1 \\
0\end{array}$ & $\begin{array}{r}-2 \\
0 \\
0 \\
+2 /-2 \\
+2 \\
-3\end{array}$ \\
\hline
\end{tabular}

+ indicates favorable statement made $_{\text {- }}$ in narrative.

$\begin{array}{llll}\text { - } & \text { negative " } & \\ \text { + } & \text { " } & \text { no statement made. } & \\ \text { " short, " etc. }\end{array}$

/ indicates both + and - statements.

* different statements made by different caseworkers.

EXAMPIES OF SCORED WORDS AND PHRASES

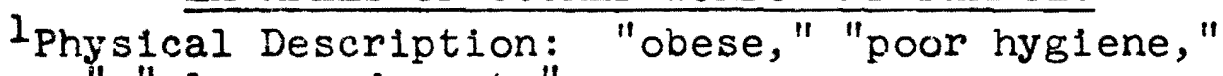
"sloppy," "clean and neat."

Affect: "depressed," "hostile," "aggressive," "immature, "anxious, "rejecting, "passive."

3parent-Child: "rejecting," "neglecting," "abusive," "loving," "well cared for."

4Home: "filthy," "dirty," "rundown," "well furnished," "cluttered, but clean." 
Developmental History

There was a vast lack of developmental information concerning fathers in our study. For the short-term cases this may be partially explained by the short-term father's general absence from home when foster care placement was needed. For long-term cases, however, where the father was generally in the home, it was surprising to see how little was known about the parents' family and their childhood.

TABLE XII

DEVELOPMENTAL HISTORY (PARENT'S EVALUATION)

\begin{tabular}{ccc}
\hline & L.T. & S.T. \\
\hline Mothers & & \\
Good & 0 & 0 \\
Poor* & 4 & 5 \\
Not Recorded & 2 & 1 \\
Fathers & & \\
Good & 0 & 0 \\
Poor* & 1 & 3 \\
Not Recorded & 5 & 3 \\
\hline
\end{tabular}

*Poor includes: "Brother's in Prison," "Deprived Emotionally and Physically," "Siblings in Foster Care," "Molested," "Grew up in Foster Care," "Married at thirteen to get away from home, "Upbringing Deprived," "Stepfather Abusive," "Financial Deprivation," "Mother had cancer and Father Drinker," "Quit School to Support Family."

From what information was recorded, there was a distinct similarity of early experiences. Where recorded, none of the individuals described their childhood as good or 
satisfying and in each case there was a preponderance of references to "unhappy," "traumatic," "dissatisfied," "deprived" circumstances.

TABLE XIII

DEVELOPMENTAL HISTORY - BY FACTORS

\begin{tabular}{|c|c|c|c|c|}
\hline \multirow[b]{2}{*}{ Economic Deprivation } & \multicolumn{2}{|c|}{$\begin{array}{l}\text { Mothers } \\
\text { L.T.S.T. }\end{array}$} & \multicolumn{2}{|c|}{$\begin{array}{l}\text { Fathers } \\
\text { L.T.S.T. }\end{array}$} \\
\hline & 2 & 3 & 0 & 1 \\
\hline Poor Par-Ch. Relat. & 0 & 0 & 1 & 0 \\
\hline Foster Care & 1 & 1 & 0 & 0 \\
\hline School Drop-Out* & 3 & 5 & 4 & 3 \\
\hline Parents Div/Sep. & 0 & 2 & 0 & 1 \\
\hline Death of Parent $(s)$ & 1 & 1 & 0 & 1 \\
\hline Alcohollc Parent(s) & 0 & 1 & 0 & 1 \\
\hline Abuse by Parent (s) & 0 & 1 & 0 & 0 \\
\hline Neglect by Parent(s) & 3 & 0 & 0 & 0 \\
\hline No Information & 2 & 1 & 5 & 3 \\
\hline
\end{tabular}

*Taken from face sheet and not from narrative. In
some cases this was the only information (history) of childhood years.

When looking at factors or circumstances most of ten noted, we included information from the face sheet (for example, schocl record) and in many cases this was the only developmental history avallable concerning the childhood 
years. For example, from face sheet information four of the long-term fathers were high school drop-outs, but in five of the six cases face sheet information was the only early history avallable in the record.

\section{Alcohol/Drugs Use}

Alcohol and drugs were examined as a problem in terms of whether the case record indicated that they were problems for the individual and affected his functioning. The incidence of alcohol/arug problems was very nearly equal in both long-term and short-term cases. It is interesting that in the long-term cases the two mothers and the two fathers noted as having a problem, came from the same two families. Thus, where alcohol/drug abuse was a problem for the longterm cases, it was a problem for both the father and mother in the family. This pattern did not exist in the short-term cases. One additional observation was made when examining the records. In the long-term cases where alcohol was a problem, the worker recorded the individual to be an "alcoholic." In the short-term cases the workers described the alcohol problem in terms of a "drinking problem." In some circles there is a commonly held notion that alcoholism contributes to long-term foster care; however, our findings did not substantiate this belief. 
TABLE XIV

ALCOHOL/DRUG USE

\begin{tabular}{lll}
\hline \hline & L.T. & S.T. \\
\hline Mothers & 2 & \\
Recorded Problem & 4 & 5 \\
None Recorded & & \\
Fathers & 2 & 2 \\
Recorded Problem & 4 & 4 \\
None Recorded & & \\
\hline
\end{tabular}

Arrest/Confinement

The case records were examined to determine incidence of arrests or confinement with the exception of traffic violations. We discovered no significant difference between long-term and short-term cases. None of the long-term mothers had an arrest or confinement record while one of the short-term mothers was arrested and confined. In this case the confinement precipitated the need for foster care and (11ke the physical illness of the mother) relates to a situational reason that foster care was required at that time. The father in this case was unable to provide for or make arrangements for child care. A father's absence, however, was not so likely to be the precipitating cause for placement as was demonstrated in two long-term cases and one short-term case. In none of these cases did the father's incarceration result in placement. 
The comparatively equal arrest/confinement history helps verify the conclusions concerning separation among long-term and short-term families. Since separations as a result of arrest and confinement are the same for both longterm and short-term cases, the difference in separation pattern at the time of placement must be the result of other factors.

TABLE XY

ARRESTS/CONFINEMENTS*

\begin{tabular}{lll}
\hline \hline & L.T. & S.T. \\
\hline Mothers & & \\
Recorded & 0 & 1 \\
Not Recorded & 6 & 5 \\
Fathers & & \\
Recorded & 2 & 1 \\
Not Recorded & 4 & 5 \\
\hline
\end{tabular}

*Minus traffic violations.

Mothers Pregnant at Time of Current Marriage

No outstanding distinguishing difference between long-term and short-term cases was noted. 
TABLE XVI

MOTHERS PREGNANT AT TIME OF CURRENT MARRIAGE

\begin{tabular}{lcc}
\hline & L.T. & S.T. \\
\hline Pregnant & 2 & 3 \\
Not Pregnant & 4 & 3 \\
\hline
\end{tabular}

Mothers Pregnant at Time of First Marriage

The results here are essentially the same as in the previous category with the addition of one pregnancy in the long-term category.

TABLE XVII

MOTHERS PREGNANT AT TIME OF FIRST MARRIAGE

\begin{tabular}{lcc}
\hline & L.T. & S.T. \\
\hline Pregnant & 3 & 3 \\
Not Pregnant & 3 & 3 \\
\hline
\end{tabular}

Military Service

The study examined the military record of the longterm and short-term fathers. Comparatively there appears to be no real difference between the record of the long-term and short-term fathers. We noted that among the long-term fathers there was one case of dishonorable discharge and one case where we could not determine the military service record. 
TABLE XVIII

MILITARY SERVICE

\begin{tabular}{lll}
\hline & L.T. & S.T. \\
\hline Honorable Discharge & 3 & 4 \\
Dishonorable Discharge & 1 & 0 \\
Not in Service & 1 & 2 \\
No Record & 1 & 0 \\
\hline
\end{tabular}

Religion

Religlous preference was noted from information ava11able on the face sheet, but because of the small sample there was no way of comparing kinds of religlous preference. We noted instead the presence or absence of a stated rel1glous preference, and thus the data simply reflects some religious involvement. Comparatively, there is no significant difference between the involvement of long-term and short-term families.

TABLE XIX

RELIGION

\begin{tabular}{lll}
\hline \hline & L.T. & S.T. \\
\hline Preference Indicated & 5 & 4 \\
No Preference Indicated & 1 & 2 \\
\hline
\end{tabular}




\section{FAMILY CHARACTERISTICS}

Number of Children in Home (at Time of Placement)

Our calculation of the number of chlldren living in the home at time of placement shows slightly larger families for the long-term cases, compared to the short-term, a difference of roughly one more child. (See Flgure II.) The one long-term case with fourteen children tends to skew the numerical difference, but as can be seen in the graph, the difference of at least one more child per family, shows up in three more of the cases also.

Th1s Figure does not show the families in their usual order, as seen in the prior tables, but rather in ascending order to illustrate this difference.

According to Jenkins, the number of children in the sibling group may reflect not only the number of children in the family, but the reason placement is needed. 40

Total Living Children

In a manner similar to the last Figure, a difference of at least one child more in long-term cases can be seen in looking at the total number of living children of the families. (See Figure III.) In fact, in this area every long-term family has at least one more child. 
No. of

Children

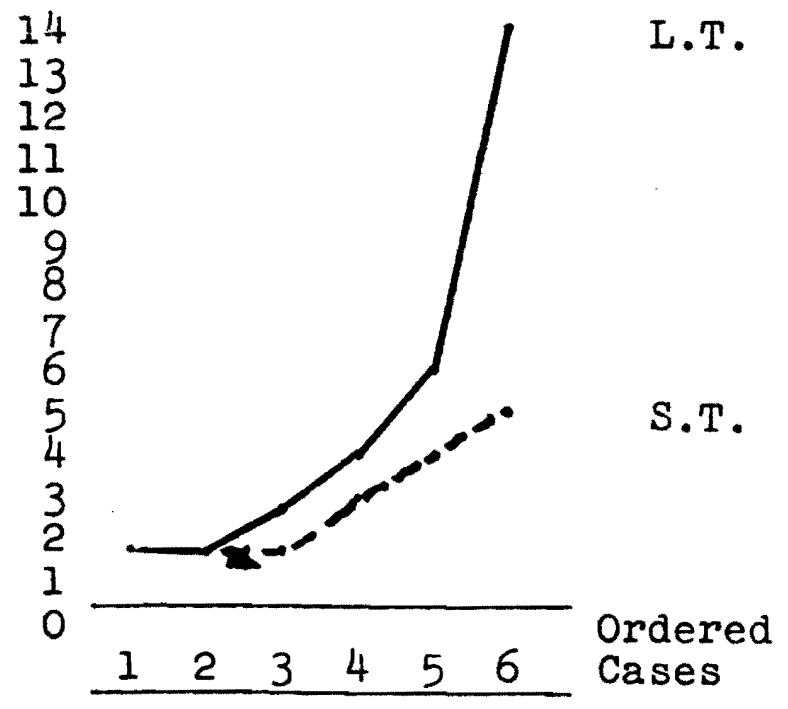

FIGURE II

NUMBER OF CHILDREN IN HOME

(AT TIME OF PLACEMENT)

No. of

Children

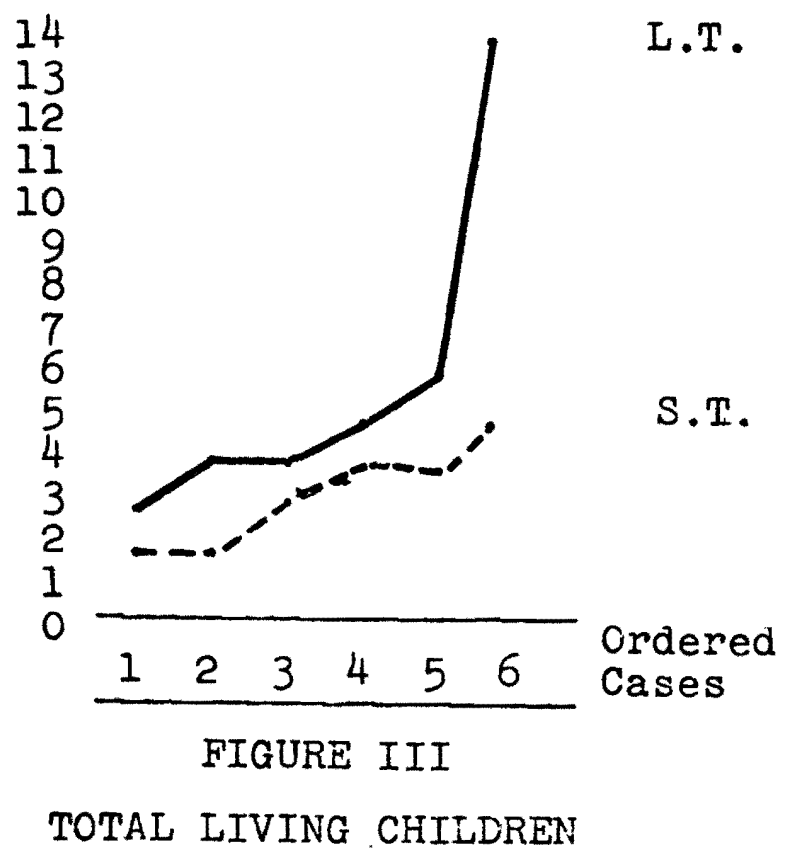


than the short-term families; thus there is in fact a larger difference in the total number of children in these two groups.

This Figure includes those children who were already In care out of the parent's home prior to the time of our placements. This Figure when compared to the previous shows an additional five children in the long-term families, and two additional in the short-term group. Of the five children in the long-term cases, three were already being cared for by friends of the family, one was being raised by an aunt, and one was already in foster care in another county. The two additional children in the short-term cases were in the custody of their father in another state, from the parents' divorce action.

Number of Chlldren Placed Out of Total in Home at Time of Placement

In looking at the number of chlldren living in the home at the time of placement, we wanted to see if all the chlldren came into care, or if there was some selectivity in the placements. Figure IV shows that in the long-term cases, the initial placements in three families did not Include all the children, as compared to one short-term case whose chlldren were not all placed, only because two were not at home when the police arrived to find the children unsupervised. In the long-term placements, two cases 
Total in Home

No. of

Chn.

L.T.

Total Placed

S.T.

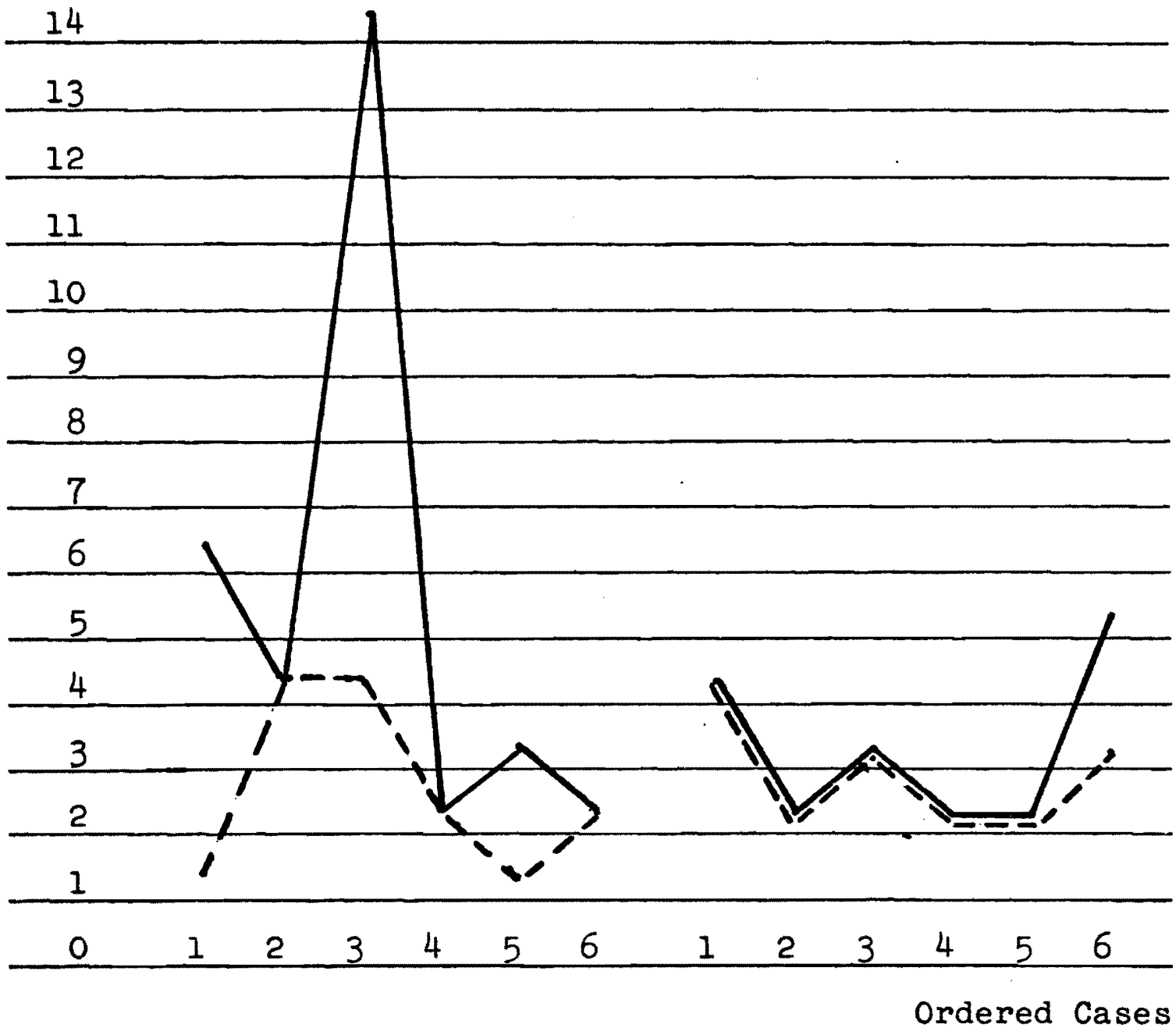

FIGURE IV

NUMBER OF CHILDREN PLACED OUT OF TOTAL IN HOME AT TIME OF PLACEMENT 
(number two and number three) attempted more than one placement of differing numbers of children in order to alleviate some of the child caring responsibility of the parents. In number two, although all four children were initially placed, two were returned to the mother upon her release from the State Hospital with the hope that she could adequately provide for them, as they were older and presumably required less care. This did not work out and these chlldren were subsequently replaced, where they remained on a long-term basis with their siblings. In number three, there were numerous placements consisting of various numbers of children. Originally the four eldest were placed to relleve some of the child care burden from the parents. Between 1966 and 1967 varlous other chlldren entered care, and some returned to the parents for differing lengths of time, culminating in September 1967 when eleven of the fourteen children were in care, where most remained for at least three years.

These seemed to be attempts in these two families to help them determine how many chlldren they could adequately handle, as compared to the short-term situational crisis situations. In the short-term a parent was hospitalized, or temporarily out of the home, but in need of child care for all the children for a specific perlod of time. In number three of long-term, there was a further problem of 
locating sufficlent foster care resources to place all the children in this family of fourteen. Seemingly because of this, attempts were initially made to place a few to see if the parents would be able to manage satisfactorily with the remainder staying in the home.

In number one and number flve of the long-term cases, placements were of one child only of family groups. These seemed to be related to particular feelings concerning those two children. They were singled out by their families as being problem children, or we felt "scapegoats," and the families' solutions were to get rid of these "problems" by placing them out of the home.

In Jenkins' study it is indicated that in those fam1lles where chlldren were placed primarlly because of their own emotional disturbances, typlcally they were the only child from the family coming into placement; whereas when hospitalization of a mother preclpitates placement, all of the chlldren in the family usually need substitute care simultaneously. This difference can aptly be seen in the differences between numbers one and five on the long-term figure, and numbers one, two, three, four, and five on the short-term figure. ${ }^{41}$ Jenkins, however, found three of five families in her study with children entering care, had only one child placed. 42 
Families Having Provided Out-of-Home Care to Children Previous to Placement

out of our sample, five of the six families whose children remained in foster care on a long-term basis had already provided for at least some of their children out of their home prior to the time of this placement.

\section{TABLE XX}

FAMILIES HAVING PROVIDED OUT-OF-HOME CARE TO CHILDREN PREVIOUS TO PLACEMENT

\begin{tabular}{lcc}
\hline & L.T. & S.T. \\
\hline YES & 5 & 2 \\
No & 1 & 4 \\
\hline
\end{tabular}

This compares with only two of the short-term cases, as far as we could tell from the avallable information.

This relates directly to Murphy's study in which he found that, in those cases of children requiring the longest term care (two plus years), the parents had had the children in care out of their home for at least four weeks at some time prior to placement. He related this to the possibility that they might have become more accustomed to not having their children with them during this prior placement, and so were able to readjust quickly, upon placement, to living without their children in the home. 43 
Jenkins, in a different way, found that $80 \%$ of her sample were cared for entirely by their mother during the year preceding placement, while in the single child placements there had been more help from outside sources preceding placement. 44

Age of Chlldren (at Placement)

We next looked at the ages of the children at the time of their placement.

TABLE XXI

AGE OF CHILDREN (AT PLACEMENT)

\begin{tabular}{lrcc}
\hline & & L.T. & S.T. \\
\hline & 17 & 1 & \\
16 & & \\
15 & 1 & 1 \\
14 & 1 & 1 \\
13 & 1 & \\
12 & 2 & \\
& 11 & 2 & 2 \\
& 10 & 3 & 1 \\
& 9 & 2 & 2 \\
& 7 & 1 & 4 \\
& 6 & 1 & 1 \\
& 5 & 2 & 3 \\
& 3 & 1 & 1 \\
& 2 & 1 & 16 \\
Total & $0-1$ & 20 & 6.5 \\
Median & & & \\
& & & \\
\hline
\end{tabular}


In those cases where there was more than one placement, our table shows those children involved in the placement which Included the most numbers of chlldren (number two and number three of long-term). The median age was used here in order to attempt to correct for the extremes, particularly the seventeen year old in the long-term group. This shows averages of 8.4 years for the long-term and 6.5 years for the short-term. The mean, on the other hand, showed averages of 7.4 years for long term, and 5.4 years for the short-term, so the median seems to bring the average up approximately one year for the two groups, but does not change to any degree, the approximate two year difference between the two groups. It seems consistent that the chlldren who remained In foster care on a long-term basis were approximately two years older than those in short-term care, at their time of placement.

Mass and Engler looked at the age of the chlldren at time of placement, and they found that most chlldren coming Into care were preschoolers, while our averages show the youngest group to be of at least kindergarten age. 45

Parental Att1tudes and Parent-Ch1ld Relationships

We next looked at parental attltudes and in doing so devised a table of attitudes that attempts to look at the ways these parents thought about, and acted toward their chlidren, on a valued scale. 
TABLE XXII

PARENTAL ATTITUDES

\begin{tabular}{|c|c|c|c|c|c|c|c|c|c|c|c|c|c|}
\hline & & \multicolumn{6}{|c|}{ MOTHERS } & \multicolumn{6}{|c|}{ FATHERS } \\
\hline & & 1 & 2 & 3 & 4 & 5 & 6 & 1 & 2 & 3 & 4 & 5 & 6 \\
\hline \multirow[t]{2}{*}{$\begin{array}{l}\text { Positive } \\
\text { Relation- } \\
\text { ship }\end{array}$} & $\begin{array}{l}\text { Demonstrated } \\
\text { love }\end{array}$ & $\mathbf{z}$ & & $z$ & 2 & 2 & $\mathbf{2}$ & & & $\mathbf{z}$ & $\mathbf{z}$ & $z$ & \\
\hline & $\begin{array}{c}\text { Concerned, } \\
\text { but. }\end{array}$ & & & & & & & & & & & & \\
\hline $\begin{array}{c}\text { Neutral } \\
0\end{array}$ & Ambivalent ${ }^{3}$ & & $z$ & $\mathrm{X}$ & & & $\mathrm{X}$ & & & & & & \\
\hline \multirow[t]{3}{*}{ Negative } & $\begin{array}{l}\text { Detached, unin- } \\
\text { volved, absence } \\
\text { of affection, } \\
\text { rejection }\end{array}$ & $\mathrm{X}$ & $\mathrm{X}$ & $\mathrm{X}$ & $\mathrm{X}$ & & $z$ & $\begin{array}{l}x \\
a b- \\
\text { sent }\end{array}$ & $\mathrm{X}$ & $\mathrm{X}$ & $\mathrm{X}$ & $\mathrm{X}$ & $\begin{array}{l}x \\
a b- \\
\text { sent }\end{array}$ \\
\hline & $\begin{array}{l}\text { Physical } \\
\text { neglect } 5\end{array}$ & & & $\mathrm{X}$ & $\mathrm{X}$ & $\mathrm{X}$ & & & & & & & \\
\hline & $\begin{array}{l}\text { Physical } \\
\text { abuse }\end{array}$ & & & & & $\bar{X}$ & & & $\mathrm{X}$ & $X$ & $\begin{array}{l}\mathrm{X} \\
\text { sex- } \\
\text { ual }\end{array}$ & & \\
\hline
\end{tabular}

L.T. $-\mathrm{X}$ S.T. $-\mathrm{z}$ 


\section{DEFINITIONS :}

1. Parent verbalized love, and his actions toward children confirmed this, (1.e., "mother appears concerned for chlldren's needs," "wanted to make home for kids," "expressed affection for children," "parents appear attentive," "had good relationship w1th kids," "talked about them a lot and responsibilities toward them," "made special trip, from California, to see kids," "parent's understanding of kids").

2. Parent verbalized love, but external c1rcumstances were interfering with their usual positive relationship, (1.e., "children were glad to see their father").

3. Parent verbalized inner conflict in feelings toward children; or sald they loved, but did not demonstrate this in actions, (1.e., "Intolerant but loved them," "loved children, but felt better in foster care," "feelings of ambivalence").

4. Parent verbalized negative feelings toward children, (1.e., "resentful of child," "did not accept children," "great responsibility given to older ch1ldren," "took little interest in," "feelings of rejection").

5. Parent falled to provide minimum adequate physical care, (1.e., "dirty house," "feces," "no heat," "physically neglected"). 6. Parent committed uncaring act toward child, (1.e." "physically abusive to
kids," "abused," "beat up k1ds," "slept with 
Th1s table ctarts with the most positive and goes to the most negative types of feelings and behaviors we could ident1fy. The table shows examples of the words used in the records which we took to indicate the parent's attitudes. Mothers and fathers were looked at individually, and were given marks around whatever area comments were made by the caseworker. Several parents were given multiple marks (1.e., mother in number three long-term) when remarks fell into several different areas. These marks then were used, based on where the majority fell, to determine the parentchild relationship, whether positive, negative, or ambivalent, as seen in the next table.

TABLE XXIII

PARENT-CHILD RELATIONSHIPS

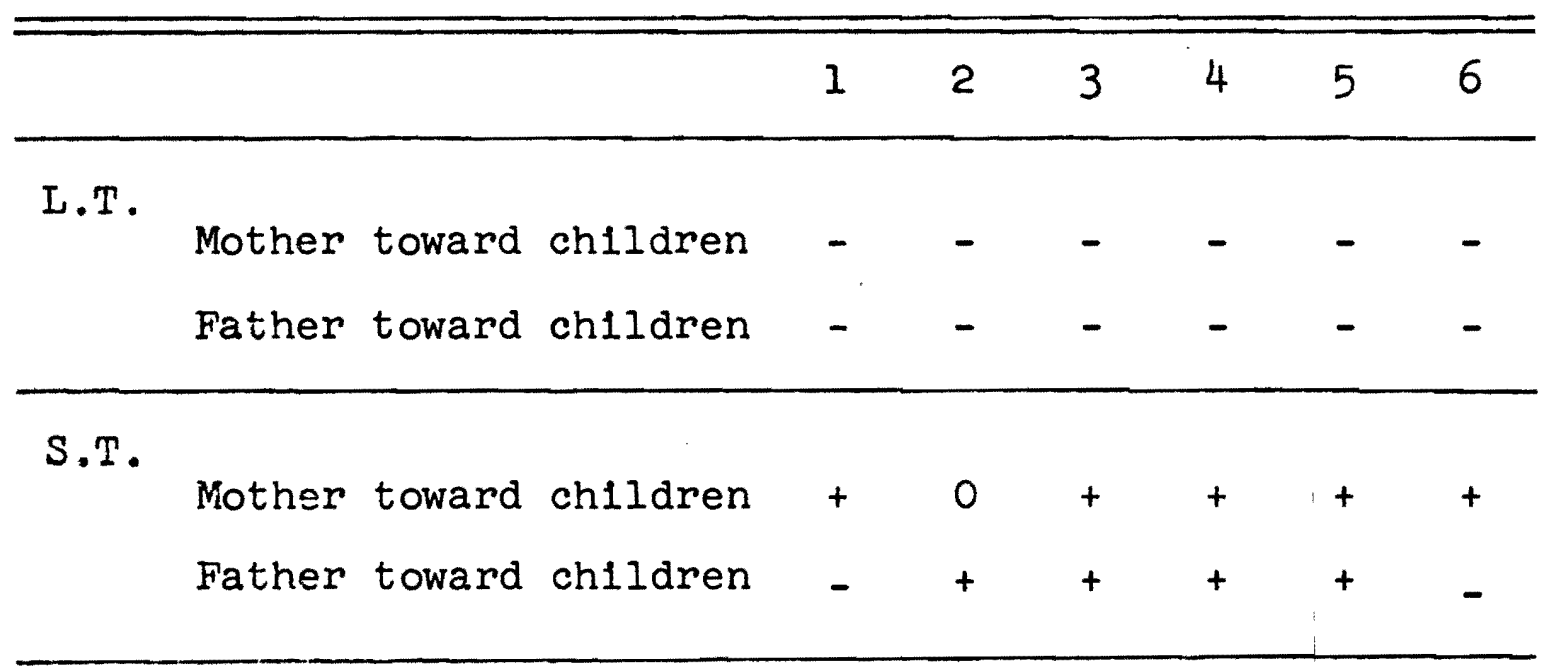

+ indicates positive relationship.

- Indicates negative relationship.

0 indicates no information or ambivalent combination of nearly equal + and - attitudes. 
The preponderance of attitudes of short-term parents fell into the positive area, while the preponderance of attitudes of long-term fell in the negative area. This can be seen spread out in the first table in order to cover the extent of comments, and combined to a single positive or negative rating in the table of parent-child relationships. It seems particularly significant, that in not one of the long-term cases did a father or mother show a generally more positive than negative attitude toward their children. This is in great contrast to the short-term parents, who in nine of twelve cases indicated a positive relationship, plus one parent who showed a combination of both positive and negative feelings. Thus these parents seem to divide dramatically in how they feel and act toward their children. In devising these tables, we attempted to also look at the children's attitudes toward their parents, but were unable to complete this due to lack of information in the records. In the long-term cases, there was no mention of children's attitudes at all, although in three of the shortterm cases some positive feelings by the children were Indicated by expressions of love and concern for their parents.

Children's Functioning (by Family)

The information about the children's functioning seemed to be significant. The comments avallable centered 
around three primary areas: health, school, and behavior. In attempting to look at one of these areas alone, there were large gaps, so we comblned these in the hopes of seeing some patterns:

TABLE XXIV

CHILDREN'S FUNCTIONING (BY FAMILY)

\begin{tabular}{|c|c|c|c|c|c|c|}
\hline & & $\mathrm{HEALTH}_{\mathrm{A}}$ & & $\mathrm{SCHOOL}_{B}$ & & BEHAVIOR $_{C}$ \\
\hline $\mathrm{L}_{i} \mathrm{~T}$ & - & Orthopedic & - & $\begin{array}{l}\text { Poor grades, } \\
\text { retarded } \\
\text { functioning }\end{array}$ & - & Medicated \\
\hline 2 & - & $\begin{array}{l}\text { Premature } \\
\text { birth }\end{array}$ & - & $\begin{array}{l}\text { Repeating } 1 \mathrm{st} \\
\text { grade }\end{array}$ & - & Hyperact1ve \\
\hline 3 & - & $\begin{array}{l}\text { Bedwetting, } \\
\text { all } 111 \\
\text { health }\end{array}$ & - & Poor achleve. & 0 & \\
\hline 4 & 0 & & 0 & & 0 & \\
\hline 5 & 0 & & - & Retardation & 0 & \\
\hline 6 & - & $\begin{array}{l}\text { Bedwetting, } \\
\text { all } 111 \\
\text { health }\end{array}$ & - & $\begin{array}{l}\text { Absences/ } \\
\text { tardiness }\end{array}$ & - & Host1le \\
\hline $\begin{array}{c}\text { S.T. } \\
1\end{array}$ & - & $\begin{array}{l}\text { Blood prob- } \\
\text { lem }\end{array}$ & 0 & & 0 & \\
\hline 2 & 0 & & 0 & & - & Temper tant. \\
\hline 3 & - & $\begin{array}{l}\text { Bronchial } \\
\text { problem }\end{array}$ & - & Slow learner & + & $\begin{array}{l}\text { Friendly, } \\
\text { outgoing }\end{array}$ \\
\hline 4 & - & Respiratory & 0 & & 0 & \\
\hline 5 & 0 & . & $-1+$ & $\begin{array}{l}\text { Slow learner, } \\
\text { but liked } \\
\text { school }\end{array}$ & + & Affectionate \\
\hline 6 & 0 & & 0 & & + & Well behaved \\
\hline
\end{tabular}


TABLE XXIV (continued)

+ Positive account of child's functioning.

- Ambivalent account of child's functioning, or no information.

- Negative account of child's functioning.

DEFINITIONS :

A HEALTH - Not including normal, routine ch1ldhood 111nesses BUT CHRONIC or RESTRICTIVE 1Ilnesses.

B SCHOOL - Children's reported experiences at school, and attitudes toward school.

C BEHAVIOR - Children's behavior as described by parent at home and recorded in narrative.

Our table assigns value to the data, positive, negative, or neutral, when discussing the children in a family as a group. Health is defined as chronic or restrictive 1llnesses, and excludes normal, childhood 1llnesses. The school category includes those comments, seen in the table, whlch describe the children's experlences at school, and any Indicated attitudes they expressed toward school. Finally, behavior is that noted by the parent in the home environment, and recorded in the narrative.

As seen in the table, there were no positive statements made about the children in the long-term cases, although some were made of the short-term children. Further, in the long-term group, we saw three families (number one, 
number two, and number six) where the chlldren were seen to have problems in all three areas; however, in no short-term case was this true. The short-term chlldren had problems in some areas, but each family group had some positive functioning in one or more areas, which possibly had a compensating effect. In fact, in only one short-term case was there more than one problem area for the children.

Jenkins' study looked at children's school performance and behavior. She reported that over forty per cent of her families reported having problems supervising their chlldren, and sixty-four per cent of the children were one or more years below their normal grade level. 46

\section{Housing}

Our information on type of housing did not seem particularly insightful.

TABLE XXV

HOUSING

\begin{tabular}{lcc}
\hline & L.T. & S.T. \\
\hline Buy & - & 2 \\
Rent & 3 & 3 \\
Share (another's home) & - & 1 \\
Not Recorded & 3 & - \\
\hline
\end{tabular}


From the information avallable, in only two of the shortterm cases and none of the long-term were the parents purchasing a home. An equal number, though, of short-term and long-term families were renting. This category did not seem to show any particular significance, except for the lack of information avallable in three long-term cases. This is especially so in view of the number of families with previous public assistance contacts which would have included the necessity of residency verification.

Jenkins looked at this area, and found that $70 \%$ of her families needing foster care were apartment dwellers. Her study, however, was done in New York City which would account for considerable difference from our cases taken in elark County, Washington. She also noted in her study that thlrty-elght per cent of her sample were dissatisfled with their housing, while a very similar number, thirty-six per eent, were not dissatisfied, but quite content in their housing arrangements. 47

Housing Condition

The description of housekeeping standards was very subjective, in that it was usually described in the records In very general terms such as "run down," "neat," or "filthy dirty." We, therefore, could only measure by using the recorder, or caseworker, as the indicator of the community standards. 
TABLE XXVI

HOUSING CONDITION - MEETING COMMUNITY

STANDARDS ${ }^{1}$ AT PLACEMENT

\begin{tabular}{lcc}
\hline & L.T. & S.T. \\
\hline Meets & 2 & 3 \\
Does not meet & 3 & 1 \\
Not recorded & 1 & 2 \\
\hline
\end{tabular}

$1_{\text {The caseworker is the "community." }}$

This then is a highly subjective category, and could only be charted to try to see broad patterns. As our table shows, there is not a great deal of difference apparent, and this information might more appropriately be a part of the caseworker's perceptions, as it is included in the previous table relating to that area.

In the Jenkins study, housing was not a factor seen to precipitate placement. Although not precipitating, she says, "deteriorated housing conditions were frequently referred to as a factor which exascerbated other problems associated with family breakdown." 48

Mobility

In this area, we also attempted to look at mobility of the families, as seen in the number of recorded moves. 
We felt, however, upon examination, that this was an unfair comparison due to the greater length of prior contact with the long-term families, which would afford us more information about their moves than the newer short-term cases. For that reason no charting was done on the data in this area.

\section{Family Financial Situation}

Our study examined the family financial situation while recognizing that generally, soclal and psychological conditions were more essentlal factors from keeping a child from returning home rather than strictly economic conditions. 49 Our intention was to combine sources of income to families and the management of that income to see if there were any apparent differences between long and shortterm cases.

Table XXVII reflects sources of income for both long-term and short-term cases and comblnes several individual categories already reported in order to identify patterns. A scoring system was chosen to distinguish differences within the categories. For example, wages were distinguished as "steady," "sporadic," and "none;" with corresponding scores of $+2,+1$ and 0 . In this way we gave a higher score to cases with a steady income which we interpreted as sign of greater financlal stability. Each case, both long-term and short-term, was rated and a score was 
totaled for both kinds of cases. Under this heading the results show little difference between long-term and shortterm cases.

A similar scoring procedure was followed in weighIng "PA Financial Dependence," "Payment of Child Support," and "Miscellaneous Use of Income." The results are IImited by the scatter of avallable information. We also recognize that the different marital status (more short-term cases were legally separated) of the two groups affects whether child support was to be paid. In spite of these handicaps, we felt that the comparative totals of +12 long-term in contrast to +26 short-term reflects a more stable financial picture for the short-term cases. 
TABLE XXVII

FAMILY FINANCIAL SITUATION -

INCOME: SOURCE AND USE

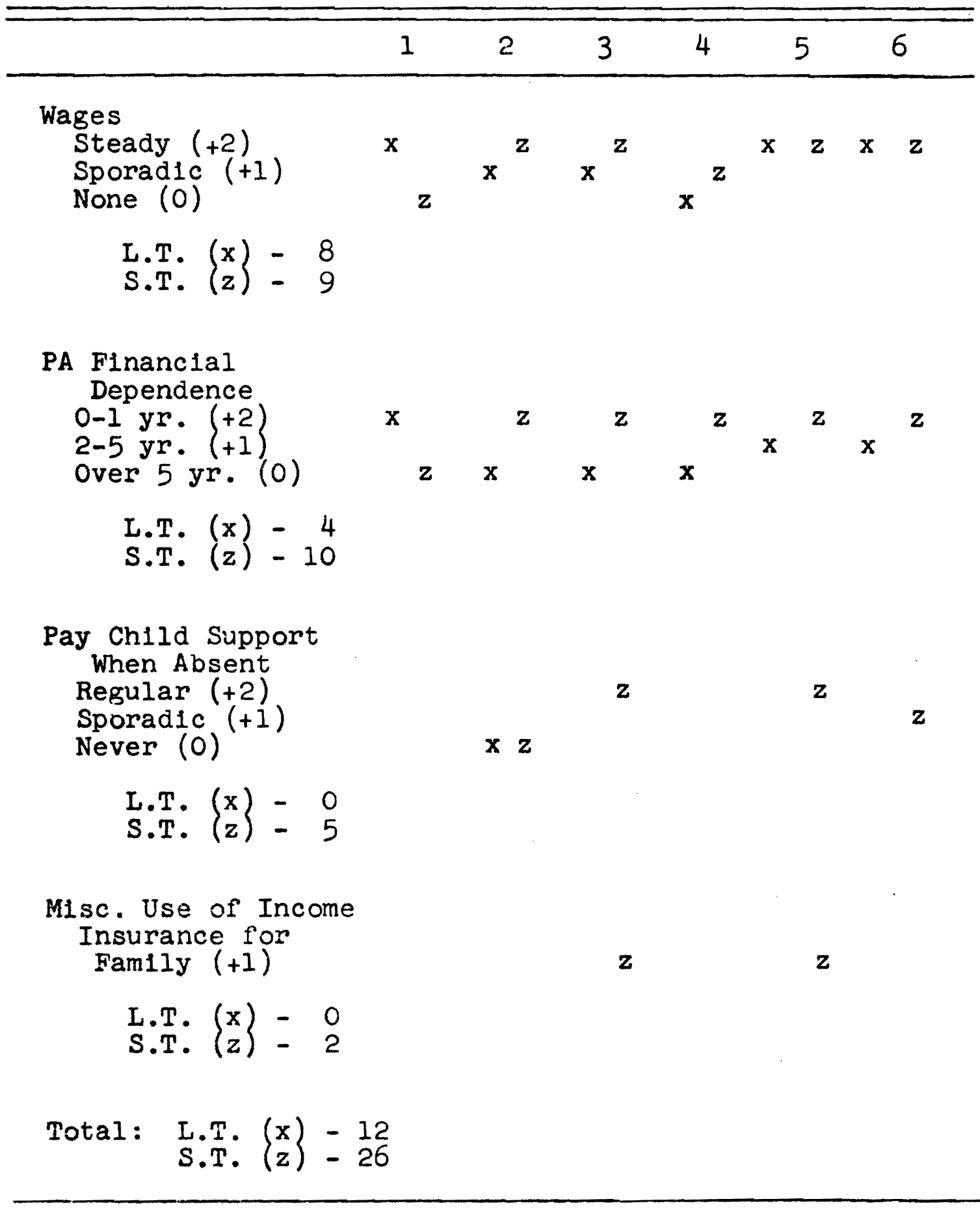


In a similar way we looked at the manner in which the short-term and long-term familles managed their income and we utilized a similar scoring procedure. From the case readIng we devised four categorles that reflect most common references to problems assoclated with money management. Each problem was scored as a minus one. For example, in the housing category, one long-term case faced eviction while another was more than six months behind on the rent and faced the dilemma of having to move. No similar circumstances surrounded short-term cases and for this category, long-term cases recelved a minus two and short-term zero. We followed this same procedure with regard to "Utility Shut off," "Bills," and "Poor Management," which was the recorded assessment of the caseworker reflected in the case record. We added these scores and totaled a minus ten for long-term cases and a minus six for short-term cases. Although the difference is not great, there appeared to be somewhat more difficult financlal circumstances among longterm cases. When we combined the differences of the two measures (plus twelve long-term versus plus twenty-s1x shortterm) of fourteen points for "Source and Use of Income" and of rour polnts (minus ten long-term versus minus six shortterm) the total spread is elghteen. From this we generally conclude as did Jenkins that the difference is one of a falrly long-term economic dependence (reflected in length of contact with PA agency and indebtedness) in contrast to a rather sudden financial crisis just prior to placement which was exemplifled by the recent separation from the husband as breadwinner. 50 
TABLE XXVIII

BAMILY FINANCIAL SITUATION MONEY MANAGEMENT

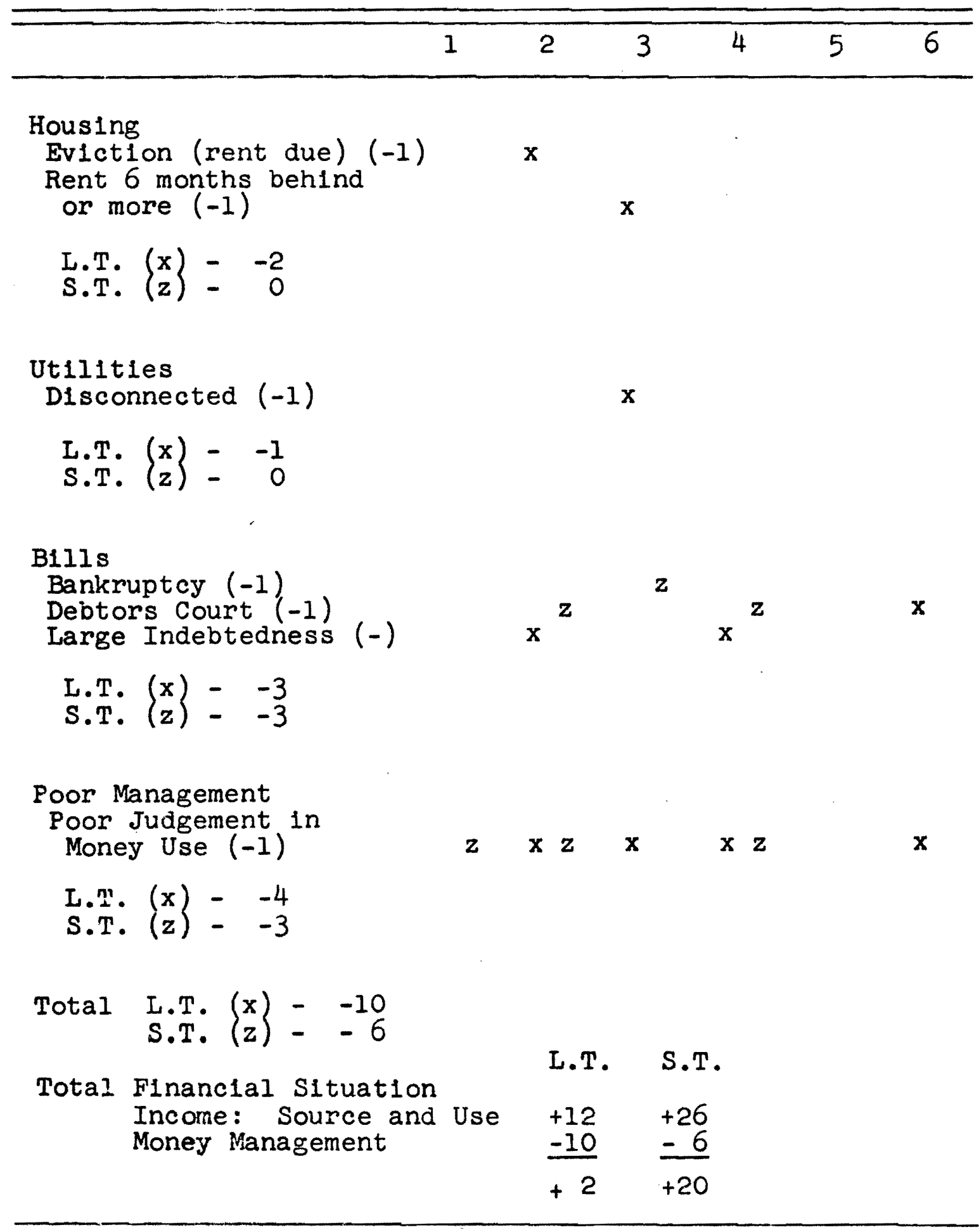


Extended Fam iy and Friends

In the area of informal resources outside the home, such as extended family and friends, we recorded those cases in which the parents 1 isted persons to whom they could turn for help.

TABLE XXIX

EXTENDED FAMILY AND FRIENDS

\begin{tabular}{llc}
\hline & L.T. S.T. \\
\hline Recorded Persons to Whom They & 3 & 5 \\
Could Turn for Help & 2 & 1 \\
No one Recorded & 1 & - \\
Negative Relationships & & \\
\hline
\end{tabular}

These included people with whom the family members had stayed in the past, and those who had offered help by takIng the children for a time. This group also included persons seen by the family as a resource even though they were never called on for help.

As seen in the table, there were slightly more resources listed by the short-term group, and only in one long-term case was there a negative relationship indicated, in which a parent had decidedly negative feelings about his family nembers and wanted no contact with them. In long- 
term case nuraber five a special situation came to light when a teacher came forward to provide care for a "problem" child who was in need.

In two of the short-term cases, a family resource used in the past for child care had broken down and was directly involved in the need for foster home care (number one and number three). In the other cases, this past relationship was not clear, and it was not possible to determine why these persons were not called upon at this time.

Maas and Engler concluded from their group that relatives or friends were involved with most of the families. 51

Length of Prior Contact with Public Assistance Agency and Protective Services Unit

There seems to be a significant difference in the length of contacts with the public assistance agency prior to placement.

TABLE XXX

LENGTH OF PRIOR CONTACT WITH PUBLIC ASSISTANCE AGENCY

\begin{tabular}{lcc}
\hline & L.T. & S.T. \\
\hline $0-1$ Year & 1 & 5 \\
$1-2$ Years & 1 & - \\
$3-10$ Years & 4 & 1 \\
\hline
\end{tabular}


In five of the six short-term cases, prior contacts were of one or less years in duration, while in four of the six long-term cases, prior contact was of at least three, and up to ten years. In eleven of the total twelve cases studied the families' first contacts were for financial assistance, rather than child welfare service. In the one exception, financial assistance was applied for, but denied; and then the case was ultimately opened in child welfare service. This frequency of prior contacts with public welfare is in direct contrast to the common assumption that casework services attached to public assistance will provide early detection and treatment of problems for families recelving public welfare.

In addition to the difference in length of prior contact, there is seen to be a difference in the quality of prior contacts.

TABLE XXXI

PROTECTIVE SERVICES UNIT INVOLVEMENT

\begin{tabular}{ccc}
\hline & L.T. & S.T. \\
YES & 3 & 0 \\
No & 3 & 6 \\
\hline
\end{tabular}


Three of the six long-term cases were carried in the special protective services unit at the time of placement where they were recelving special services for their family problems, as compared to none of the short-term cases, all of whom were subsequently carried in the regular child welfare services units.

In three cases, one long-term and two short-term requests had been made for foster home placement at a prior time, but service was denied or the family was referred to the Juvenile department, only to have the children come into care at this later time.

Jenkins found in her study that forty-nine per cent of the families were recelving public assistance at the tIme of placement. Of these, forty-elght per cent had been on public assistance continuously two or more years prior to placement, which led her to make the implication that "the majority of public assistance families (needing placement) had had long dependency problems rather than a group which had sudden emergency need for support." 52

An attempt was made to look at the number of caseworkers these families had had to deal with prior to placement, but this seemed untenable due to the differing time frames of past agency contacts, so no table was completed in this area.

Community Agencles Involved

The other community agencies involved with these families were many and varled. 
TABLE XXXII

COMMUNITY AGENCIES INVOLVED

(OTHER THAN P.A.)

\section{L.T. S.T.}

\begin{tabular}{|c|c|c|c|}
\hline \multirow[t]{2}{*}{$\begin{array}{l}\text { COURTS AND } \\
\text { LAW ENFORCE- } \\
\text { MENT }\end{array}$} & $\begin{array}{l}\text { CLARK COUNTY JUVENILE COURT } \\
\text { OTHER JUVENILE COURT } \\
\text { TRAFFIC COURT } \\
\text { SUPERIOR COURT } \\
\text { CITY POLICE } \\
\text { COUNTY SHERIFF }\end{array}$ & $\begin{array}{l}4 \\
1 \\
0 \\
1 \\
0 \\
2\end{array}$ & $\begin{array}{l}4 \\
0 \\
1 \\
1 \\
2 \\
0\end{array}$ \\
\hline & TOTAL & 8 & 8 \\
\hline \multirow[t]{2}{*}{$\begin{array}{l}\text { PENAL } \\
\text { INSTITUTIONS }\end{array}$} & $\begin{array}{l}\text { STATE REFORMATORY } \\
\text { OTHER STATE PRISONS }\end{array}$ & $\begin{array}{l}2 \\
0\end{array}$ & $\begin{array}{l}0 \\
1\end{array}$ \\
\hline & TOTAL & 2 & 1 \\
\hline \multirow[t]{2}{*}{$\begin{array}{l}\text { MEDICAL } \\
\text { FACILITIES }\end{array}$} & $\begin{array}{l}\text { HEALTH DEPARTMENT } \\
\text { COUNTY HOSPITAL } \\
\text { OTHER HOSPITALS }\end{array}$ & $\begin{array}{l}1 \\
0 \\
0\end{array}$ & $\begin{array}{l}0 \\
2 \\
2\end{array}$ \\
\hline & TOTAL & 1 & 4 \\
\hline \multirow[t]{2}{*}{$\begin{array}{l}\text { COMMUNITY } \\
\text { PSYCHOLOGICAL } \\
\text { SERVICES }\end{array}$} & $\begin{array}{l}\text { MENTAL HEALTH CLINIC } \\
\text { SCHOOL PSY. SERVICE } \\
\text { GOOD SAM. CHILD STUDY } \\
\text { DELAUNEY } \\
\text { WASHINGTON STATE HOSPITAL } \\
\text { OTHER STATE HOSPITALS }\end{array}$ & $\begin{array}{l}2 \\
3 \\
1 \\
1 \\
1 \\
1\end{array}$ & $\begin{array}{l}1 \\
0 \\
0 \\
0 \\
0 \\
0\end{array}$ \\
\hline & TOTAL & 9 & 1 \\
\hline \multirow[t]{3}{*}{$\begin{array}{l}\text { EMPLOYMENT } \\
\text { AND TRAINING }\end{array}$} & $\begin{array}{l}\text { LABOR \& INDUSTRIES DEPT. } \\
\text { D V R }\end{array}$ & $\begin{array}{l}1 \\
1\end{array}$ & $\begin{array}{l}0 \\
0\end{array}$ \\
\hline & TOTAL & 2 & 0 \\
\hline & OTHER WELFARE AGENCY & 1 & 2 \\
\hline
\end{tabular}


Table XXXII includes all those agencles mentioned in the case records as belng involved with these twelve families, and the numbers of long-term and short-term families with whom they were in contact. As seen, there is a wide varlety of agencles represented, although taken in groups they tend to deal with a few general kinds of areas such as courts and law enforsement, penal institutions, medical care, psychological services, and employment and training. There is extensive contact with the juvenile courts In these cases, both long-term and short-term, which in many cases was related to the need for child welfare services and foster care at the time of placement. There also, however, was considerable contact by long-term cases with psychological services, of varying kinds, in contrast to only one contact in the short-term cases. The scatter for agencles is general to both long-term and short-term except for this one area.

Voluntary/Involuntary Placement - Complaints

The study examined the parental attitude concerning placement to determine whether placement was in accordance with parental wishes. We included as voluntary those cases where juvenile court action was taken when 1 t was as a result of the parents' wishes. A placement was considered involuntary when the parents opposed the placement and the 
children were removed by court action or police authority. Numerically, the voluntary/involuntary pattern was identical for both long-term and short-term cases. In the short-term cases, however, the involuntary placement was the result of the chlldren being unsupervised and picked up by police and taken to juvenile authorities without the parents' knowledge. In these two cases the children were returned within two days after consideration of the family situation. In the involuntary long-term cases, placement was the result of court action at which time the court mied against the parents' wishes. This practice is made clearer when we consider complaints of child care relative to long-term and short-term cases.

TABLE XXXIII

VOLUNTARY/INVOLUNTARY PLACEMENT

\begin{tabular}{lll}
\hline & L.T. & S.T. \\
\hline Voluntary & 4 & 4 \\
Involuntary & 2 & 2 \\
\hline
\end{tabular}

The complaints of child care registered with the agency were numerically similar, with complaints recorded in three long-term cases and two short-term cases. It is signiflcant, however, that the complaints registered on the 
three long-tern cases were instrumental to court action and placement. In the short-term cases the complaints were incldental to the other factors that contributed to the reasons for placement.

TABLE XXXIV

COMPLAINTS OF PARENTAL CARE

\begin{tabular}{lcc}
\hline & L.T. S.T. \\
\hline & 3 & 2 \\
Complaints Recorded & 3 & 4 \\
None Recorded & & \\
\hline
\end{tabular}

Shirley Jenkins found that seventy-five per cent of the families she studied had no opposition to placement where 1llness and/or emotional problems of the child was the reason for placement. On the other hand, only twenty-one per cent of the families favored placement in neglect/abuse cases.

This data contradicts the popular notion that in the majority of families, placement of children is a worked out and thought out process involving parental initiative and agreement to placement as the preferred plan for the child. 53

Reason for Placement

Shirley Jenkins felt strongly that some estimate of duration of placement was possible, knowing the total family situation. 
Although se cannot use data to predict the future of any child, there is a strong implication that the reason for placement is a primary factor to be considered in planning for the length of time in care. 54

For the purposes of our study we looked at the pattern of factors that came together at the time of placement as the single most important reason foster placement was required at the specific time the decision to place was reached. We attempted to apply Jenkins' five categorles for differentiating reasons for placement. Jenkins used the category "Physical Illness/Incapac1ty" to Include cases where the child caring parent was absent from the home for a temporary period of time due to hospitalization as a result of physical illness. She also included mothers confined due to a pregnancy. As a reason for placement, twenty-nine per cent of the cases she studied fell into this category. "Mental Illness of the Mother" category reflected the incapacitation of the mother as a result of mental breakdown. Eleven per cent of the cases Jenkins studied required placement for this reason. The category "Children's Personal Problems" reflects a varlety of chlldhood problems both physical and emotional. Mental retardation, hyperactivity, physical handicaps, etc., are included in this category. A consplcuous feature is that the problem is defined in terms of the child with an absence of reference to the parents. Th1s category made up seventeen per cent of the cases Jenkins 
studied. "Severe Neglect/Abuse" refers to inadequate parental care in terms of omission (fallure to provide basic food, shelter and care) and commission (severe physical acts directed at the child). In Jenkins' study, ten per cent of the cases were of this nature. The "Family Problems" category reflects a varlety of problems that attack the family and includes marital conflict, alcohol and drug abuse, incarcerations and other problems associated with the relationship between parents and children. Jenkins found a third of her cases f'ell into this category.

TABLE XXXV

REASON FOR PLACEMENT

\begin{tabular}{|c|c|c|c|c|c|c|}
\hline & 1 & 2 & 3 & 4 & 5 & 6 \\
\hline $\begin{array}{l}\text { Physical Illness/ } \\
\text { Incapacity }\end{array}$ & & z & $\mathbf{z}$ & & $\mathbf{z}$ & \\
\hline $\begin{array}{l}\text { Mental Illness - } \\
\text { Mother }\end{array}$ & & $x$ & & & & \\
\hline $\begin{array}{l}\text { Child's Personal } \\
\text { Problems }\end{array}$ & $x$ & & & & $\mathbf{x}$ & \\
\hline $\begin{array}{l}\text { Severe Neglect/ } \\
\text { Abuse }\end{array}$ & & & $x$ & $\mathbf{x}$ & $\mathbf{x}$ & \\
\hline Family Problems & $x z$ & & $x$ & z & $\mathbf{z}$ & $x z$ \\
\hline
\end{tabular}

We found that the short-term cases clustered in two areas: "Fhysical Illness/Incapacity" and "Family Problems." 
Long-term cases clustered in the "Family Proslems" and "Severe Neglect/Abuse" categories. In some cases there were clearly two reasons of nearly equal importance noted and we related this to Jenkins' observation of cases where there were multiple factors/reasons for placement.

Jenkins found that families grouped under the designation "Family Problems" most likely had multiplicity of reasons for placement. She concluded:

Where problems other than physical 1llness, mental or emotional illness were primarily involved, there was usually a multiplicity of factors, and a simple child care substitute without supportive services was unlikely to be the answer to preventing child placement. 55

Where placement resulted from mother's hospitalization, this group had the fewest multiple reasons for placement. Jenkins concluded:

- that where physical 1liness or confinement led to placement, these reasons dominated the case picture and tended to stand alone. Where there were contributory factors it tended to be unwillingness or inablilty of others to care, which indicates that services related to provision of child care substitutes (homemaker, housekeeper) might have averted placement in a number of cases. 56

Four short-term cases required placement when the mother was temporarily absent from the home because of confinement in a hospital (three cases) or temporary incarceration (one case). Two of the short-term placements terminated prior to the mother's release when alternatives were evaluated and the chlldren's fathers could make arrangements to care for the children. 
Jenkins found a significant difference in duration of care among the five categories. For chlldren entering care because of confinement of the mother, fifty-four per cent of the children returned home
- . under one week, and none was found to be in care after three months. In contrast, for children entering care because of personality or emotional problems, only three per cent returned home in under a week and eighty- five per cent were in care after three months. Dura- tion of care tended to be similar for children placed because of the mother's mental illness (fifty-two per cent long-term), severe neglect and abuse (sixty-five per cent long-term) and family problems (sixty-two per cent long- term) categories. 57

our study tends to confirm Jenkins' results as three shortterm mothers were confined in hospitals and another was Incarcerated temporarlly which typifies short-term placement cases that Jenkins found in her study. Two long-term cases in our study resulted from the child's personal problems which is Jenkins' category that reflects the greatest percentage of long-term placements.

More speciflcally, the 1llness/confinement category in our study reflects many of Jenkins' findings. The emergensy nature of the problem, the fact that there was little recourse to alternative arrangements at the time of placement, and the characteristic of a one parent household, were features of this category that were common to both our study and the Jenkins study. The situational nature of the problem and the general absence of complicating factors 
related to the short-term nature of the placements in this group. In her experlence, Jenkins noted several instances where public assistance workers, according to the clients, did not appear to be fully aware of the health problems or to be involved in planning for the care of the children durIng a known anticlpated period of in-hospital treatment. This c1rcumstance was equally apparent in two of the shortterm cases as they came to the agency requesting placement, but were directed to the juvenile court who made the placement on an "emergency" basis.

In the mental 1llness of the mother category a recurring feature was the lack of evidence of planning for the children in the event of hospltalization. This factor was present in one long-term case in our study. In this case a sulcide attempt precipitated hospitalization and minimized any planning for the children.

In the category of child's personal problems Jenkins noted the high percentage of intact families and single child placements. These factors held true for our study and reflects concentrated focus on the child as the source of the family difficulties. This category produced the greatest asceptance of placement as the only solution to the child's problems and thus the tendency for few children to be returned in three months or less appears as an understandable conclusion to these factors. 
The severe neglect/abuse category produced a family situation resulting in placement from problems of a longterm chronic nature. There were notably no sudden precipitating changes as were found in families where physical 111ness of the child caring person was the primary cause of placement. Jenkins found a pattern of long-term economic dependency rather than a financial crisis prior to placement. The household arrangement tended to be constant durIng the year prior to placement but characterized by bitter family arguments and severe neglect and mistreatment of the children. Jenkins found children in this category typlcally older and again the duration of foster care was likely to be long-term. Two of our long-term cases followed this pattern while none of the short-term placements consisted of child neglect/abuse as a factor precipitating placement. Jenkins characterized the family problems category as the "apparent inability of parents to sustain child care roles" and said "this was indicated by the large variety of child care arrangements reported at the time of placements (only fifty-four per cent of the chlldren Jenkins studied were entirely cared for by the parents)."58 we found that more than twice as many long-term families (five long-term, two short-term) had made prior arrangements for chlld care out of their own home before the placement under study and typically these parents did not attempt to plan alterna- 
tives. Although noted earlier, Maas and Engler's conclusion bears repetition where they note that the difference whether children return home relates to the parent's ability to plan for the child.59 In cases where children did not return home, there was an absence of a plan or conflicting plans concerning what was to take place. 


\section{CHAPTER IV: IMPLICATIONS}

In this chapter we shall examine the results of the data in light of inferences drawn from the sample and implications they may present for further research.

The reader will find the following discussion somewhat repetitious of preceding material. The points reiterated, however, are important to the clarity and utility of this study for further research.

\section{LIMITATIONS}

The findings of this study correlate favorably in many respects with other, more extensive studies done in the area of foster care. The results support the findings of Murphy, Jenkins, and Maas and Engler, as pointed out specifically in Chapter III. There are limitations to the validity of this study, however, that should be briefly reviewed. These limitations are due primarily to sample size and subjectivity of data.

The criteria used for case selection, outlined in Chapter II, was an attempt to Identify a sample of "pure" cases on the extreme ends of a continuum of short to longterm foster care cases. Thus, many cases were eliminated from the sample, leaving a very small number of acceptable cases that fit the research design. 
The time span of one year, from which the sample was drawn, eliminated variances resulting from an increased or decreased target population which often occurs within a one year period. Furthermore, the total foster child population during the selected period was not significantly disproportionate to that of the year preceding or following 1t. However, it is unknown if the target population may be unusual compared to that of any other time period.

The nature of the sample, being case records only, limits the objectivity of the study. Most of the descriptions of Individual and family characteristics are colored both by the perspective of the caseworker recording the data and the researchers' interpretation.

The frequency of relevant data found to be insufficlently recorded or totally absent from the records further limited the researchers' abllity to present more complete character descriptions and, therefore, draw significant Inferences.

When the 1959 Child Welfare League of America's Standards for Foster Care were published, there came into existence an expliclt guideline for workers to use in recording a family social summary. This guide included such Items as parental developmental history, observed current social functioning, assessment of soclal, psychological and parental strengths and weaknesses, and formulation of ini- 
tlal and ongoing casework plan of treatment. It is interesting to note that in very few of the case samples did we find explicit information recorded in the manner outlined by these standards relative to parental developmental history, particularly of fathers, and the caseworker's assessment of family strengths.

The absence of information in those areas germane to what the Social Work profession considers a good soclal summary and assessment raises the question of the feasibility of sound planning for duration of foster care and treatment necessary for the family.

As stated in the 1959 Child Welfare Standards for

\section{Foster Family Care:}

Duration of foster family care and the ultimate outcome of this service should be determined by the needs, age and problems of the child, the nature of his relationships with his parents and siblings, and the extent of parental capacity. 60

Furthermore:

A tentative prognosis should be made as to the length of placement and whether the outcome will be return of the child to his own home, long-term care or termination of parental rights. 61

We do not want to imply that because information in the areas of social diagnosis and planning was absent from the records, there existed no plan either for placement or casework with the famlly. We would wonder, however, about consistency of case planning in those cases that are trans- 
ferred from one caseworker to another without the benefit of recorded developmental, assessment and prognostic data.

\section{AGENCY NETWORK AS A VARIABLE}

There are variables inherent in the agency related to policy and practice which are operative behind the scenes of the case samples that should be brought into perspective.

One of the internal factors we have already discussed at length is the recording of data in the case records. The information we found in most of the records was little more than statements made by workers, giving an account of what was said or done by their clients.

At the time the case samples were known to the agency, caseworkers were responsible for a large number of persons requiring casework services. The average caseload consisted of between sixty to one hundred families, which, broken down, could mean three to four hundred individuals or more.

Prior to 1970, child welfare workers had, in addition to providing services, the burden of determining financlal eligibility of their assigned cases and keeping current financlal paperwork on each case. The size of caseload, in addition to the time involved in performing clerical duties, left the caseworker little time to provide meaningful case- 
work services to individual families, let alone find time to evaluate and record meaningful data for each individual case.

Given the conditions under which caseworkers were functioning, the implications of the lack of data suggests poor organization within the agency system. It would seem unrealistic, for example, to expect caseworkers to provide meaningful services to three hundred individuals and maintain clerical efficiency. Furthermore, meaningful recording would seem to be dependent on adherence to a model designed for effective case evaluation and planning. Caseworkers and their supervisors should assume more responsibility for adherence to such a model.

We did find recording in short-term cases which conformed somewhat to the guide for recording previously mentioned. With only one exception these short-term cases became known initially to the agency within one year prior to 1967. Coincidently, in the latter part of 1966 a speclalized child welfare intake unit was created in the agency. This intake unit was designed especially for screening all incoming child welfare referrals to the agency. The unit had the explicit task of obtaining background information on each individual family member, assessing the problem, and elther providing the necessary services (for up to ninety days) or referring the case to ongoing 
service workers for follow-up casework. Thus, it appears in the sample that consistency in recording background and vital statistic data did not occur until the inception of the intake unit in 1965.

We also noted that all but one of the short-term cases were handled only by child welfare caseworkers. All of the long-term cases were transferred to child welfare workers from family service workers at the time placement was eminent. The slight difference found in the quality of recording after the time of transfer may be an implication of child welfare workers' superior recording practices, or, an implication of efforts on the part of all staff to conform to a recording guide during the selected time period.

Since the time from which the sample was taken, changes have come about in agency structure and function with the inception of Declaration - Specialization. "Dec-Spec" essentially separates financial services from social services. This change in agency structure frees the caseworker from concern for financlal ellgiblilty factors, allowing him or her to concentrate more on providing social casework services.

Along with this structural change has also come a new form of recording, aptly called "form recording." Caseworkers now write out brief narratives under specific headings on a form designed to focus more on diagnostic and planning data. 
Although 1t does have its limitations, the form recording method should enhance consistency of recorded data, elimInate much nonrelevant data found in the former method of recording, and provide more meaningful data for further research.

INFERENCES AND IMPLICATIONS FOR FURTHER RESEARCH

As previously stated, the study presented here is an attempt to identify differences in family characteristics found in long-term and short-term foster care cases which may provide predictive potential relative to planning for children entering foster care. The inferences drawn from the data are intended, therefore, to 1dentify possible significant areas for further research. In addition, they are intended to provide a focus for development of an instrument which may predict parents' ability to provide continuing care for their chlldren following foster care placement. In our discussion of inferences we shall examine them in order of their relative significance, beginning with those characteristics in which we found the sample groups to be Identical or very similar. Since we were looking more for differences to be developed in a predictive instrument, similarities and only slight differences between the groups are not considered as significant as the marked differences presented at the end of this chapter. 
Those characteristics in which we found very slight differences or very close similarities may be significant in making inferences about parents (as a group) whose children require foster care placement. However, they cannot be generalized to that group, as a whole, without considering them in perspective with the broader agency client population, and without using a much larger sample.

Two areas we found of no particular significance were the birthplace of parents and the fathers' military record. The former may be more indicative of moblilty found in the larger soclety than a particular characteristic of families requiring the agency's services. The fathers' military record--whether or not he was in the service, and whether or not he had an honorable discharge--may give us some insight about the father personally, but may not be indicative in itself of his role functioning in the family.

We found no religious differences between the groups. All the cases in which a religious preference was recorded claimed themselves "Protestant." The number of Protestants was not surprising since the general population recelving the agency's services are predominantly Protestant. Child Welfare services for Roman Catholics in the community are provided almost exclusively by Catholic Chlldren's Services. Other religlous groups have such a low population ratio in the community as to be insignificant. Also, the fact that 
there was only one racial minority group member in the sample is indicative of the small nonwhite population in the community, the largest of which are Blacks. Census figures for Clark County, c1ted in Chapter II, indicate that the Black group represents less than one per cent of the total population.

In our examination of records for "religlous" information, we were more interested in the involvement of the family with their particular churches rather than just categorizing families by denominations. We found mention in only one case of any involvement with the church. We, therefore, do not know to what extent, if any, religion is important to the families we examined; further, to what extent religion may influence family strengths and need for foster care placement of the child(ren).

Whether a family is buying a home, renting, or sharIng someone else's home may have implications regarding the general stabllity of a family economically and socially. The information found in the sample infers the short-term group to be slightly more stable than the long-term group, using this criterion. Only two families in the short-term group were buying a home, compared to none in the long-term group. However, we have no knowledge of housing arrangements in one-half of the long-term cases. 
The type of housing arrangement, as described above, may be assoclated with other factors as employment and money management. Job stability, amount of income, and financial planning infer a family's degree of social-economic security. This security, in turn, may affect the parents' ability to provide for their children's needs.

We noted that there seemed to be only slight differences between the groups in the type of employment held by the fathers. Skilled and unskilled employment appeared falrly evenly distributed, and there was only a very slight difference in whether the fathers' employment was steady or sporadic. The contrast was found in the number of shortterm mothers having had some employment history at a rate of two to one, compared to the long-term mothers. Th1s difference in mothers' employment histories infers an economic potential in favor of the short-term group that may have an impact on total family functioning. However, the correlation between economic potential and crises leading to family disruption requires further exploration than what is presented here.

There was no recorded information in most of the cases relative to the amount of annual income earned from employment. Since all but one of the cases came to the agency's attention initially because of financlal need, we assume the annual income level for both groups to be at or 
below the poverty level, with the short-term group belng slightly better off financlally than the long-term group. This assumption relative to income level is supported by the duration of dependence on public assistance funds found for each group, as well as differences found in the area of money management. These differences in employment and financlal management appear also to correspond with the slightly higher educational level of the short-term group. The most significant contrast between the two groups is more apparent in the duration of financlal dependence than in the areas of income and educational level. The long-term group's longer duration of financial dependence is an implication of that group's social-economic disorganization.

Because of the avallability of public assistance funds to sustain a family's physical needs, financial status should not in itself be a determinant factor in foster care placement. We did note, however, in one long-term case, the mother's mental health, which was a precipitating factor to placement, was influenced directly by the family financlal situation. Also in one other long-term case the juvenile court judge removed two of the children from the famlly because there were too many chlldren for the parents to care for adequately. 
Although there appeared to be multiple problems in each case, alcohol was recorded as a problem in less than one-third of the long-term families, as well as the shortterm families. In the long-term cases, in which alcohol was considered a problem, the label "alcohollsm" was used by the recorder; "problem drinking" was used for the short-term cases. These terms may have been accurate assessments of existing conditions. However, in view of implications drawn from other evidence inferring the caseworkers' perception, which are presented later, the labels may be indicative of perceptive discrepancies made by the caseworker.

Both groups also had similarly few incidences of arrests for infractions other than traffic violations and Jail or prison incarcerations.

Thus, it appears in the sample that the social ills of alcoholism and crime are not general characteristics of the majority of families requiring placement of their children, or in determining duration of foster care.

Whether or not the mother was pregnant at the time of legal marriage was a factor we hoped may glve us some Insight about differences in the marital relationships and parental attitudes toward their children entering foster care. This factor alone, however, falled to show any differences between the two groups. Premarital pregnancy does not appear in this study to have any significant bearing on 
duration of foster care. Although premarital pregnancy may affect the marital and parent-child relationships, further study is needed in order to infer cause and effect relationships of these factors.

From the areas of least significance we now move to those characteristics in which the sample groups showed slight differences. These differences examined in a larger sample may prove to be more significant than indicated here. Further research on these characteristics may be valuable to predicting duration of foster care.

The number of children per family appeared to ind1cate a slight difference between the two groups studied. The long-term group averaged about one child more per family unit. The correlation of this phenomenon with Jenkins' findings, cited in Chapter III, suggests that larger families found in long-term foster care cases is more than mere colncldence. The factor of one more child per family, combined with socio-economic and intrafamily relationship data, could be highly significant to duration of foster care.

The number of children placed, compared to the number left in the home in long-term families, is significant. The selection of children for placement is particularly significant when viewed from the perspective of the prevalence of more chronic crises in long-term families versus temporary, situational crises of the short-term cases. W1th one excep- 
tion, the latter required immediate alternative care arrangements for all the children in a family rather than selecting only certain children for placement.

In our examination of the parents' ages at the time of their marriage and again at the time their children were placed in foster care, we found the long-term group, as a whole, to be a little older than their short-term counterparts. Also, the ages of the long-term children at the time of placement appeared, on an average, to correlate with their parents' age difference from the short-term group. The comparison of our observations of age differences to Murphy's, and Maas and Engler's studies, cited in Chapter III, indicates a significant degree of importance for further study on the influence of parent-child age factors on duration of foster care.

In the area of housekeeping standards, the long-term group fared slightly below the short-term group. HousekeepIng standards may affect to some degree the social acceptance, or approval of a mother and her ability to care for her chlldren. Our middle class soclety seems to judge the worth of a woman on her ability to keep a home clean and attractive. Her standards of housekeeplng also seem to be associated with her ability to care for her children properly. For example, a poor housekeeper may be thought of as a negligent mother. We can only consider that information 
found in the area of housekeeping as part of a cluster of factors indicating the families' degree of disorganization. In no case did we find poor housekeeping standards to preclpitate placement.

The short-term group appeared slightly above the long-term group in having close relatives or friends nearby listed as resources in case of emergency, yet more long-term families used friends or relatives to provide substitute care for their children sometime prior to placement. The Implications of this phenomenon may be in a difference of how parents in each group view their friends or relatives as resources. There were cases in both groups in which friends or relatives were used as a financlal resouree, or to provide temporary housing or child care. Considering, however, the predominance of negative parental attitudes toward their children in the long-term group, these human resources appear to be used more by this group to relleve themselves of their child caring burden, rather than as a resource to keep the family unit together.

We found the most signiflcant discrepancles between the sampled cases to lie in the areas of marital status at the time of placement, parental health status, parent-child relationship, reason for placement, and the caseworkers' perception of the families. These factors are seen as the focus upon which criteria for predicting duration of foster care, as well as future foster care planning, can be bullt. 
The difficulty in evaluating the marital relationship, in terms of conflicts resulting in separation or divorce, and how this may affect duration of foster care is influenced by the agency's having more knowledge of separations in the long-term cases through longer contact. Also, some of the separations occurring in both groups were because of the fathers' incarceration, and may not particularly reflect marital conflict.

It is interesting to note that at the time of placement, one long-term father was incarcerated, yet his wife considered him as still a part of the family unit. Furthermore, the majority of long-term couples were considered to be married and together while the majority of the short-term couples were physically separated due to factors other than the fathers' incarceration. The virtue of being married and together, according to society's standards, does not appear In the sample to have positive implications for the longterm group. Thus, we may conclude for the sample that duration of foster care is determined by factors other than the continuity of the marital union.

The return of children to single parent households in the short-term cases further indicates the father's absence (or, in one case, the mother's absence) was not a deterrent to the children's return home. 
In those long-term cases in which the children suffered severe neglect or abuse by one of their parents, the marital status may have actually been a contraindicator for returning the children home, as long as the abusing parent remained. This contraindicating factor could be implicated in one-half of the long-term cases sampled.

Information relative to the areas of physical and mental health problems reveals marked differences between the two groups studied. The long-term group is characterlzed by more chronic illness, as well as a higher frequency of reported emotional problems. The short-term group is characterized by more temporary, acute health problems, which, in one-half of these cases, precipitated placement of their children.

The differences in health status are reflected further in the preponderance of state and community mental health facilities involved with the long-term group versus physical health facilities found dealing more with the short-term group. "Physical and mental health facilities" is the only area of "other community services involvement" revealing a significant difference between the two groups sampled.

We can speculate that 111 health may be an important factor in the parents' social and interpersonal functioning. We can see in some of the cases sampled that parental health 
status does affect the individual's economic and social functioning ability. In other cases the parents' emotional stress is directly correlated with their intrafamily relationships.

We have been able to record some of the possible underlying factors in parental attitudes which affect the parent-child relationship. The degree to which the longterm parents suffer financlal and soclal deprivation, compared to their short-term counterparts, as well as the higher incidence of mental 111 health and more chronic physical 1llness, help explain the factors related to the discrepancles found in the parent-child relationship.

The combination of factors stated in the above paragraph, related to the parent-child relationship, can be seen manifested in the childrens' health, school and soclal behavior. As indicated by the table in Chapter III, the long-term children appear to have more problems in the three areas listed than the short-term children.

The reasons for placement are in themselves significant in further lllustrating differences between long-term and short-term foster care cases. The reasons for placement appear to be indicative of the type and degree of social, blological and psychological pathology characterIstic of each group studied; therefore, their implications are significant in terms of the factors they represent. For 
example, severe neglect found as a reason for placement in the long-term group is highly significant when viewed in perspective of a long history of social dysfunctioning and existing intrafamily relationships.

Even in the absence of formally recorded evaluations in the sample, it is interesting to note the predominance of positive statements made by caseworkers about the short-term families and the absence of any made about long-term fam1lies. The researchers have interpreted the implications of positive and negative statements to reflect the caseworkers' perception of the parents in the sample.

The caseworker is seen as holding a position of keepIng the children out of the home or returning them by his or her own authority or through influence in the juvenile court. The caseworker's evaluation or perception of the parents would logically seem to influence his or her decision for or against returning the children to their parents. We might add, however, that the authority does not rest entirely with the caseworker, but is shared frequently w1th the courts.

\section{FACTORS NOT EXAMINED}

Areas of possible significance that we were unable to examine in this study are: the relationship between the agency and the parents, cooperative or not, positive or 
negative; the actual case plan for treatment of the parents, actual services given, and prognosis of success or fallure. Other unknown factors having possible influences on duration of foster care are: avallability of sultable foster homes for the agency's use, the extent of parents' accessibility to a varlety of helping services in the community, the agency's relationship with existing community resources, and avallablilty of alternatives to foster care placement such as use of homemakers, day care centers, etc.

\section{CONCLUSION}

From our research efforts we see the parent-child relationship emerging as a significant focal point from which to bulld an hypothesis on predictive determinants of duration of foster care placement. Other signiflcant factors as the families' social and economic dysfunctioning, and particularly the degree of physlological and psychological pathology, are seen as integral influences on the relationship. The reason for placement and the perception of the caseworker are seen as products of the factors integrated into the intrafamily relationships, and therefore, are significant in determining duration of foster care. The feaslbility of a follow-up study, based on the findings presented, appears to be favorable. In the 
researchers' opinion, the findings provide a substantial base for development of a scale of characteristics associated with duration of foster care and parental functioning ability .

A predictive scale for duration of placement may prove valuable in furthering research into other areas of foster care planning, as well as an effective tool for practical application to current casework practice. 


\section{FOOTNOTES}

\section{${ }^{1}$ Standards for Foster Family Care (New York: Child Welfare League of America, 1959), p. 4.}

${ }^{2}$ Ibid., p. 7 .

${ }^{3}$ Shirley Jenkins and Mignon Sauber, Paths to Ch1ld Placement: Family Situations Prior to Foster Care: (New York: Community Council of Greater New York, 1966), p. 198.

${ }^{4}$ Neglected-Battered Child Syndrome (New York: Child Welfare League of America, 1963), p. 5.

5eontine Young, Wednesday's Children: A Study of Child Neglect and Abuse (New York: McGraw-Hill Book Company, 1964), pp. 100-110.

${ }^{6}$ Ib1d., p. 102.

7 Ibid.

8 Vincent DeFrancis, "Fundamentals of Child Protection," Child Protective Services in the United States (Denver: American Humane Association, 1955), p. 114.

$9_{\text {United Nations Children Deprived of a Normal Home }}$ Life (New York: United Nations Department of Social Affa1rs, 1952), p. 11.

${ }^{10}$ Standards for Foster Family Care, p. 6 .

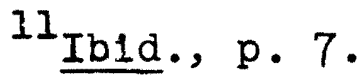

12 Rosemary Dinnage and M. L. Kellmer Pringle, Foster Home Care: Facts and Fallacies (London: Longmans, Green and Company, Ltd., 1967), p. I.

13 Children's Bureau, Foster Care of Children (Washington, D.C.: U. S. Printing office, 1966), p. 1 .

${ }^{14}$ Jenkins and Sauber, 10c. cit. 
15 Henry Maas and Richard Engler, Children in Need of Parents (New York: Columbia University Press, 1959).

${ }^{16}$ Helen D. Stone, Reflections on Foster Care (New York: Child Welfare League of Amer1ca, 1969), p. 34.

17 John Bowlby, Maternal Care and Mental Health (New York: Schocken Books, 1966), p. 114.

18 Henrietta Gordon, "Long-Time Care," Child Welfare (January, 1950).

${ }^{19}$ Dinnage and Pringle, o․ cit., p. 29.

20 Bernice Madison and Michael Shapiro, "Permanent and Long-Term Foster Family Care as a Planned Service," Child Welfare XLIX (March, 1970) p. 131.

${ }^{21}$ Richard Haltch, Orphans of the Living: The Foster Care Crisis (New York: Child Welfare League of America, 1968), p. 2 .

22 Jenkins and Sauber, op. c1t., p. 200.

23R. A. Parker, Decision in Child Care (London: George Allen and Unwin, Ltd., 1966), p. 30 .

24 Madison and Shap1ro, op. c1t., p. 133.

25

Ibid.

26 Jenkins and Sauber, op. cit., p. 76.

27 Claire Selltiz, et. al., Research Methods in

Soclal Relations (New York: Hoit, Rinehart, and Winston, 1951), pp. 59-65.

28 Ibid., p. 64.

${ }^{29}$ State of Washington Pocket Data Book, Office of Program Planning and Fiscal Management, January, 1971, p. 167.

${ }^{30}$ Ibid.
${ }^{31}$ Ibid., p. 246. 


\section{${ }^{32}$ Ibid., p. 167.}

33The description of the agency and foster care placement statistics was obtained through the examination of a child welfare memorandum prepared by the social service supervisor dated June 30, 1966 as well as through interviewing the present social service supervisor and the current child welfare services supervisor.

\section{${ }^{34}$ Leontine Young, op. cit., p. 6.}

35These examples are created by abstracting general characteristics from all the cases studied, and putting them together to illustrate what any one family in each category might most resemble.

36 Jenkins and Sauber, op. c1t., p. 35.

37 H. B. M. Murphy, "Predicting Duration of Foster Care," Child Welfare, 48:76-84 (February, 1968), p. 77.

${ }^{38}$ Maas and Engler, op. c1t., p. 277.

39 Jenkins and Sauber, op. cit., p. 49. ${ }^{40}$ Ibid., p. 22.

${ }^{41}$ Ib1d.

42 Ib1d.

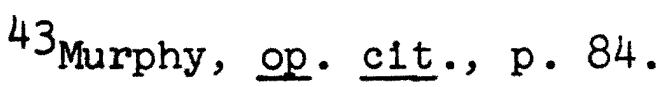

44 Jenkins and Sauber, op. c1t., p. 53.

${ }^{45}$ Maas and Engler, op. cit., pp. 41, 111, 180, 272. 46 Jenkins and Sauber, op. c1t., pp. 57-58.

47 Ib1d., p. 40.

48 Ibid.

49 Maas and Engler, op. c1t., p. 352.

50 Jenkins and Sauber, op. cit., p. 148. 
125

${ }^{51}$ Maas and Angler, op. cit., p. 275.

52 Jenkins and Saber, op. cit., p. 44.

53 Ibid., p. 76 .

54 Ibid., p. 79.

${ }^{55}$ Ibid., p. 70 .

${ }^{56}$ Ibid., p. 67 .

57 Ibid., p. 182.

58 Ibid., p. 166.

59 Maas and Angler, <compat>op. cit., p. 356.

${ }^{60}$ Standards for Foster Family Care, p. 6.

${ }^{61_{\text {Ibid. }}, \mathrm{p} .13 .}$ 


\section{BIBLIOGRAPHY}

Adler, J. "Separations--A Crucial Issue in Foster Care," Journal of Jewish Communal Service, 46:305-13

(Fall and Summer, 1969).

Andrews, Roberta G. "When is Subsidized Adoption Preferable to Long-term Foster Care," Child Welfare, 50:194-201 (Apri1, 1971).

Bowlby, John, et. al. Maternal Care and Mental Health. New York: Schocken Books, 1966.

Brown, Gordon E. (ed.). The Mult1-Problem Dilemma. Metuchen, New Jersey: The Scarecrow Press, Inc., 1968 .

Bryce, Marvin E., and Roger C. Ehlert. "144 Foster Ch1ldren," Ch1ld Welfare, 50:499-503 (November, 1971).

Clemens, C. L. "Continuity Through a Lasting Parentship," Public Welfare, $27: 338-43$ (October, 1969).

DeFrancis, Vincent. Child Protective Services in the Urited States. Denver: American Humane Association, 1956.

Dinnage, Rosemary, and M. I. Kellmer Pringle. Foster Home Care: Facts and Fallacies. London: Longmans, Green and Co., Ltd., 1967.

Ellsworth, Phoebe C., and Robert J. Levy. "Leglslative Reform of Child Custody Adjudication," Law and Soclety Review, 4:167-234 (November, 1969).

Fanshel, D., and H. S. Maas. "Factorlal Dimensions of the Characteristics of Children in Placement and Their Families," Child Development, 33:123-44 (March, 1962).

Foster Care of Children. Washington, D.C.: Children's Bureau, 1966.

Foy, Edward. "The Decision Making Problem in Foster Care," Child Welfare, 46:498-503 (November, 1967).

Gelsmar, L. I., and Michael A. LaSorte. Understanding the Mult1-Problem Fam1ly: A Conceptual Analysis and Exploration in Early Identification. New York: Association Press, 1964. 
Gerson, David. Patterns of Soclal Functioning in Families w1th Marital and Parent-Child Problems. Toronto: University of Toronto Press, 1967.

G11, David G. "Developing Routine Follow-up Procedures for Ch1ld Welfare Services", Child Welfare, 43:229-40 (May, 1964).

Gordon, Henrietta. "Long-Time Care," Child Welfare, 29: 3-8 (January, 1950).

Ha1tch, Richard. Orphans of the Living: The Foster Care Crisis. New York: Public Affairs Committee, 1968.

Jaffe, Ellezen D. "Correlates of Differentlal Placement Outcome for Dependent Children in Isreal, "Soclal Service Review, 41:390-400 (December, 1967).

Jenkins, Shirley. "Duration of Foster Care: Some Relevant Antecedent Variables," Child Welfare, 46:450-55 (October, 1967).

Jenkins, Shirley and Elaine Norman. "Families of Ch1laren in Foster Care", Ch1ldren, 16:155-59 (July-August, 1969).

Jenkins, Shirley, and Mignon Sauber. Paths to Chlld Placement: Family Situations Prior to Foster Care. New York: Community Council of Greater New York, 1966.

Jenkins, Shirley. "Separation Experiences of Parents Whose Ch1ldren are in Foster Care," Child Welfare, 48:33439 (June, 1969).

Jeter, Helen R. Children's Proulems and Services in Child Welfare Programs. Washington, D.C.: Children's Bureau Publication, 1963.

Kline, Draza. "The Validity of Long-Term Foster Family Care Service," Child Welfare, 44:185-95 (Apr1l, 1965).

Lew1s, Mary. "Foster-Family Care: Has it Fulfilled Its Promise," The Annals of the American Academy of Political and Soclal Science, Edited by Thorsten Sellin. (Alan Kelth Lucas, Speclal Editor of this Volume.) Philadelphia: The American Academy of Political and Soclal Sclence, 1964. 
Lew1s, Mary. "Long-Time Temporary Placement," Child Welfare, 30:3-7 (October, 1951).

Low, Seth. Foster Care of Children: Major National Trends and Prospects. Washington, D.C.: Children's Bureau, 1966.

Maas, Henry, and Richard Engler. Children in Need of Parents. New York: Columbia University Press, 1959.

Madison, G., and Michael Shap1ro. "Permanent and LongTerm Foster Family Care as a Planned Service," Child Welfare, 49:131-36 (March, 1970).

Mulford, R. M., and M. I. Cohen. Neglecting Parents--A Study of Psychosocial Characteristics. Denver: American Humane Association, 1968.

Murphy, H. B. M. "Natural Family Pointers to Foster Care Outcome," Mental Hygiene, 48:380-95 (July, 1964).

Murphy, H. B. M. "Predicting Duration of Foster Care," Child Welfare, 48:76-84 (February, 1968).

Parfit, Jessie (ed.). The Community's Children. London: Longmans, Green and Co., Ltd., 1967.

Parker, R. A. Decision in Child Care. London: George Allen and Unwin, Ltd., 1966.

Sauber, M. "Preplacement Situations of Families: Data For Planning Services," Child Welfare, 46:443-9 (August, 1967).

Selltiz, Claire, et. al. Research Methods in Social Relations. New York: Holt, Rinehart, and Winston, 1951.

Standards for Foster Family Care. New York: Child Welfare League of America, 1959.

State of Washington Pocket Data Book, Office of Program PIänñng and FIscal Management, January, 1971.

Stone, Helen D. Rerlections on Foster Care. New York: Ch1ld Welfare League of America, 1969.

The Neglected-Battered Child Syndrome. New York: Child Welfare League of America, 1963. 
United Nations Children Deprived of a Normal Home Life. New York: United Nations Department of Soclal Affairs, 1952.

Watson, K. W. "Long-Term Foster Care: Default or Design," Child Welfare, 47:331-38 (June, 1968).

Weaver, E. T. "Long-Term Foster Care: Default or Design: The Public Agency Responsibility," Child Welfare 47:339-45 (June, 1968).

Young, Leontine. Wednesday's Ch1ldren. New York: McGrawH11l Book Company, 1964. 